Arqueología y Sociedad,

№ 23, 2011

\title{
Chavín de Huántar y la definición ARQUEOLÓGICA DE UN ESTADO TEOCRÁTICO ANDINO
}

Henry Tantaleán*

\section{Resumen}

En este artículo se propone que el sitio arqueológico de Chavín de Huántar fue la materialización y el centro de un Estado Teocrático Andino. Para darle sustento a dicha propuesta se plantean una serie de indicadores arqueológicos los cuales surgen de la información acumulada y actualizada como también de nuestras propias observaciones. Con tal propuesta inspirada en el materialismo histórico se espera generar una discusión centrada en los objetos arqueológicos y que atienda a las condiciones materiales particulares y a la trayectoria histórica de los Andes centrales.

Palabras clave

Estado, teocracia, Andes, materialismo histórico.

\begin{abstract}
In this article we propose that the archaeological site of Chavin de Huántar was the materialization and center of a Andean theocratic state. To give support to such proposal we argue a serie of archaeological indicators which ones raise from the accumulated and updated information as well as own observations. With such proposal inspired in the historical materialism we expect generate a discussion focused on the archaeological objects and that attend to the particular material conditions and to the historical trajectory of the central andes.
\end{abstract}

Keywords

State, theocracy, andes, historical materialism.

* Universidad Nacional Mayor de San Marcos / Instituto Francés de Estudios Andinos, Lima. Correo electrónico: henrytantalean@yahoo.es 


\section{INTRODUCCIÓN}

Desde los comienzos de nuestra disciplina, los investigadores del pasado nos hemos enfrentado al reto de otorgarles nombre a los fenómenos sociales pasados con los que trabajamos. Para ello hemos generado, en tanto heurísticas, categorías, conceptos o nombres que nos ayudan a acercarnos y comprender mejor dichos fenómenos. Obviamente, cada una de estas etiquetas se origina y parte de una concepción del mundo y, para nuestro caso, de una teoría arqueológica (implícita o explícita) que le da sentido y contenido a estos fenómenos sociales dentro de nuestro ordenamiento de dicho mundo pasado en el presente. Históricamente, los fenómenos sociales que hemos estudiado han sido vistos a la luz de diferentes teorías aunque las evidencias materiales de dichos fenómenos puedan ser las mismas. Obviamente, también existe una carga política, acéptese o no, en la generación de dichas categorías y en los últimos años esto ha sido hecho evidente y sido criticado y asumido desde la misma arqueología.

Dentro de estos fenómenos por estudiar, la aparición u origen del Estado prehistórico siempre ha estado en un lugar bastante privilegiado puesto que como ente político que genera un quiebre en la forma de vida pasada hasta nuestros días es importante para explicarnos a nosotros mismos como sociedad. Además, dado que nuestro oficio está relacionado directamente con los objetos, y casi desde el principio por el gusto por las cosas que poseen una gran calidad estética y durabilidad, las creaciones realizadas por los Estados antiguos, que poseen una mayor capacidad para generar dichos objetos, han llamado la atención de los arqueólogos y arqueólogas y de la sociedad en general. Así pues, este debate acerca de la aparición del estado y sus correlatos materiales ha generado una importante literatura en la cual se aprecian diferentes líneas de investigación pero, sobre todo, diferentes teorías que suponen su existencia, carácter y concreción (por ejemplo ver Service 1984[1975], Haas 1982, Lull y Micó 2007).

En los Andes, como la misma historiografía señala, casi siempre la explicación del origen o aparición del estado ha estado condicionada por estudios o teorías que han sido generados en lugares alejados donde se planteó por primera vez la existencia del Estado temprano, que es el que más llama la atención por su carácter primigenio, "prístino", "de primera generación" o "primario" (Millaire 2010a, Spencer 2010). De esa forma, se han generado características o elementos arqueológicos que deben estar presentes tanto allá como aquí para vindicar a un fenómeno arqueológico como el Estado, casi siempre dejando de lado la forma de producir la vida social en condiciones particulares, como es el caso del mundo andino.

Por lo anteriormente comentado, creemos que además de esas epistemologías y modelos arqueológicos-antropológicos hegemónicos, mayoritariamente neoevolucionistas, otras formas de comprender el pasado también pueden contribuir a generar una representación o explicación más adecuada a la realidad social de los Andes prehispánicos. Así pues, en este artículo planteamos una definición del estado teocrático andino y que también surge como una propuesta teórico-práctica que nace desde la evidencia concreta y que pretende superar dialécticamente a la ampliamente utilizada categoría de "Jefatura Compleja" ("Complex Chiefdom") ${ }^{1}$ y que se aplica a diferentes sociedades que no alcanzan a cubrir los requisitos necesarios para ser definidas como un estado, como en el caso de Chavín de Huántar (por ej. Manzanilla 2001: 401). Dicha categoría fue generada y es utilizada ampliamente por la arqueología procesualista neoevolucionista anglosajona (Service 1962, Flannery 1972, 1998, Earle 1987, Johnson y Earle 2000)² o inspirada en ella que, para el caso peruano, principalmente, es de origen norteamericano (por ejemplo, ver Haas y Creamer 2006) ${ }^{3}$. Dicha categoría daría cuenta, principalmente, de una organización sociopolítica intermedia entre las sociedades simples y los Estados y que se ma-

1 Para una síntesis del uso de la "complejidad" en arqueología ver Adams 2001 y para una aplicación en los Andes centrales ver Haas y Creamer 2006.

2 También ver Chapman 2008 para una crítica de la hegemonía de los "modelos angloamericanos" con especial referencia a la utilización de la categoría de "jefatura".

3 Aunque ver una crítica al neoevolucionismo aplicado a los Andes en Pozorski y Pozorski 1992: 863. 
terializaría en la concentración de arquitectura monumental más allá de la capacidad de las unidades domésticas y que tiene un territorio y una población importante aunque también intermedia entre esos dos extremos de la escala evolutiva de las sociedades. Más importante y a nivel antropológico esta categoría explica que en dicho tipo de sociedad no existirían clases sociales o explotación de un grupo social hacia otro sino más bien mecanismos (extraídos de la antropología económica) que explicarían la monumentalidad mediante la redistribución (Johnson y Earle 2000) (incluida la asimétrica) y la existencia de líderes carismáticos ${ }^{4}$ o "Big Men" que generan u obtienen su "prestigio" mediante el auspicio y ofrecimiento de grandes banquetes instalados y celebrados en dichos espacios monumentales 5 .

4 En versiones procesualistas más modernas y autocríticas (procesuales-duales), como la de Blanton et al. (1996), que tratan sobre cómo operan los líderes en las "sociedades complejas" se pueden encontrar la división entre las estrategias de poder exclusionistas ("exclusionary") donde los líderes individuales generan relaciones de dominación de tipo patrón-cliente con los sujetos de la sociedad y se empoderan mediante redes con otros líderes ("network") gracias a las cuales obtienen el acceso a bienes exclusivos y las estrategias de poder corporativas ("corporate") donde la elite se apoya en los grupos de la misma sociedad para conservar ("compartir") el poder político y económico (compárese con las "jefaturas individualizantes" ("Individualizing Chiefdoms") y las "Jefaturas orientadas hacia el grupo" ("Group-oriented Chiefdoms") de Renfrew 1974 en Blanton et al. 1996). También ver Manzanilla 2001.

5 Por ejemplo, en un reciente artículo, Charles Spencer (2010: 7119) retomando a Henry Wright (1977) señala que: "Wright definió a la jefatura como una sociedad con autoridad centralizada pero no especializada internamente; él definió al estado como una sociedad con una organización administrativa centralizada y también internamente especializada, coherente con el concepto Weberiano de burocracia racional. La autoridad de la Jefatura es, de este modo, centralizada pero no burocrática, un diseño que encuentra su expresión lingüística en los relativamente pocos términos empleados para designar a los encargados de tomar las decisiones en las jefaturas etnográfica y etnohistóricamente documentadas. En contraste, incluso los estados relativamente pequeños presentan una gran cantidad de denominaciones de puestos administrativos". De tal manera, para Spencer como para Wright, el principal rasgo del estado es que el líder o autoridad estatal puede derivar o delegar autoridad y/o tareas a otros especialistas: una burocracia constituida con jerarquías que asuman autoridad parcial. Esta autoridad parcial se vería arqueológicamente en otros centros políticos fuera del principal y otorgaría la territorialidad necesaria al estado.
Esta categoría procesualista es ampliamente usada antes de la aparición de sociedades que comparten los elementos claves de los "estados de primera generación" de otras parte del mundo como se plantean para el caso de Moche, Wari o Tiwanaku, ubicados posteriormente a los inicios de nuestra era (Stanish 2001, Manzanilla 2001, Billman 2002, Silverman 1995, Schreiber 2001, Smith y Schreiber 2005, 2006).

No obstante, creemos que mediante la evidencia arqueológica disponible en la actualidad también es posible caracterizar objetivamente a las sociedades que mostraron una desigualdad socioeconómica y sociopolítica, evidente en la forma asimétrica de conducir y consumir el trabajo de un grupo social por otro (explotación) mediante prácticas coercitivas y normas institucionalizadas amparadas y justificadas en un sistema religioso que funcionaba para reproducir dicha asimetría social, léase estado teocrático. Claramente esta propuesta está basada en una perspectiva de los objetos arqueológicos materialista histórica que trata de explicar a Chavín de Huántar no solamente como consecuencia de una evolución general universal de las sociedades sino más bien como producto históricosocial con sus propias condiciones materiales de existencia y relaciones sociales específicas y particularidades históricas donde, en un tiempo determinado en su trayectoria histórica, un grupo de la sociedad halló las condiciones necesarias, aunque generadas por la misma sociedad, para ubicarse ventajosamente con respecto a otros individuos y produjo artefactos e instauró practicas para sancionar, controlar y/o manipular a otros individuos con el objetivo de reproducir dicha situación ventajosa, mediante "tecnologías del poder" (Foucault 1976), en este caso las prácticas religiosas coercitivas y sus materializaciones.

El estado teocrático como concepto ya había sido propuesto inicialmente por Luis G. Lumbreras Salcedo ${ }^{6}$ (por ejemplo, 1974: 72, 1981: 189, 1993: 373, 2005[1989]: 273, 2005[1995]: 222, 2007: 662) para el caso de

6 Interesantemente, Childe (1947:73) también había planteado un "Despotismo Teocrático". 
Chavín de Huántar ${ }^{7}$ donde él veía un poder político y económico en manos de "especialistas" religiosos (también ver Bate 1984: 72) ${ }^{8}$. Sin embargo, el historicismo cultural, evolucionismo y occidentalismo instalado e imperante en el pensamiento arqueológico dominante en el Perú en general no permitió consolidar este concepto y su comprobación empírica. Esto tendría que ver, entre otras razones, con la necesidad de utilizar categorías universales desarrolladas en otras áreas pero soportada con evidencias arqueológicas producidas histórica y localmente. Es decir, dichas categorías universales que nunca fueron generadas aquí deberían contener los mismos elementos o atributos arqueológicos encontrados en los primeros Estados del mundo más que en nuestra propia realidad. En ese proceso, confundíamos el fenómeno o apariencia con su causa o esencia ${ }^{9}$, de tal modo que, lo que había ocurrido principalmente en Cercano Oriente (básicamente por la influencia childiana) debería haber tenido las mismas manifestaciones concretas en los Andes. Por ello, esta propuesta también tiene como objetivo general comenzar a generar una teoría arqueológica andina que dé cuenta de las manifestaciones concretas de las prácticas sociales en la región andina que en algunos casos han demostrado ser originales (por ejemplo, ver Burger (1992: 226) para Chavín de Huántar o Makowski (2003, 2008a, 2008b: 7) para el urbanismo andino).

En este artículo, si bien, utilizamos el materialismo histórico (como teoría general y epistemología) que también es una ciencia y filosofía de origen occidental ${ }^{10}$, el mismo Karl Marx

7 Para otras propuestas cercanas sobre estados teocráticos, también ver Fung 1988, 2008[1999] para Las Haldas o Pozorski (1987: 15) y a los Pozorski (Pozorski 1987, Pozorski y Pozorski 1994: 70) para Pampas de las Llamas-Moxeque.

8 Sin embargo, la categoría "Estado Teocrático" está más relacionada con la sociedad Moche de tiempos posteriores a Chavín (Canziani 2008: 195). Interesantemente es el mismo tiempo en el cual los arqueólogos procesualistas aceptan la existencia de estados en los Andes.

9 Por ejemplo, lo mismo sucede con la categoría de "ciudad" que veremos más adelante.

10 Ver críticas al materialismo histórico por dicha carga etnocéntrica en Patterson 2008. entendía que cada situación histórica tenía su propia manifestación en lo concreto. En consecuencia, nuestro materialismo histórico asume que dadas ciertas condiciones materiales y relaciones sociales históricamente producidas generarán concreciones diferentes en distintos espacios/tiempos aunque con la posibilidad de encontrar formas y relaciones de producción similares en otras partes del mundo y en otros momentos históricos.

Si bien, muchas veces se ha caído en el mecanicismo y la ortodoxia, por ejemplo, cuando se trataba de encajar a las sociedades del Nuevo Mundo en los modos de producción sugeridos por Marx, creemos que en este caso él estaba generando esquemas generales y que, como sabemos, necesitaba de mayor información empírica para poder plantear sus generalizaciones ${ }^{11}$ (Bate 1984). Como sabemos, el método científico materialista histórico parte de lo específico para llegar a lo general y viceversa, en una superación o movimiento dialéctico que se va adecuando a lo que expresa la realidad concreta. No obstante, este principio básico marxiano no fue lo suficientemente comprendido por propios y extraños, lo que se puede ver claramente en los debates de la década del 70 de siglo pasado en el Perú cuando se discutía intensamente sobre el modo de producción, en especial el asiático, en los Andes prehispánicos (Espinoza 1981[1978]. También ver Bate 1984). En todo caso, se puede decir que el debate fue mas teórico que empírico

11 Creemos que muchas de las confusiones con relación a los escritos marxistas se originan en la aplicación mecánica de los modos de producción y su sucesión en el tiempo pero, sobre todo, en el evolucionismo social explícito existente en textos como "El Origen de la Familia, la Propiedad Privada y el Estado" de Engels (1976[1884]) quien toma como parte sustantiva de dicho trabajo la investigación etnológica de Lewis Morgan quien plantea ciertos elementos, sobre todo, los tecnológicos como los medios "revolucionarios" que hacen que se pase de un estadío a otro. Asimismo, en el texto de Engels se toma como una forma universal de coerción a los especialistas o guerreros (Engels 1976[1884]:168). En este caso, no se atiende a formas diferentes o más tempranas de ejercer la violencia institucional, como puede ser la ejercida mediante las prácticas religiosas (aunque ver nuestro indicador 8). De hecho, en el libro mencionado solo se hace referencia someramente a los desarrollos andinos de la época del contacto español. 
lo cual se mantuvo también en la misma propuesta de Lumbreras que nunca desarrolló una metodología arqueológica para contrastar dicha propuesta teórica del estado andino y especialmente su origen relacionado a lo que denominó Estado Teocrático ${ }^{12}$.

Obviamente, la contradicción principal para poder generar una teoría arqueológica del Estado Andino está en que, por un lado, existirían principios y manifestaciones universales del Estado y, por el otro, las condiciones materiales concretas serían especificas en el mundo andino lo que sumado a una perspectiva presentista conduciría a un particularismo histórico esencialista ("Lo Andino", "Andinismo" (Isbell 1999: 24, Jamieson 2005: 353, Sendón 2006). Nosotros creemos que la ubicación en cualquiera de esos dos extremos perjudica la concepción y consecuente comprobación de un fenómeno particular en los Andes (la forma, apariencia) pero que, también, rehúye a las cuestiones generales y de fondo (esencia) del Estado prehispánico y del estado en general y más importante, la existencia de la desigualdad social institucionalizada. Entonces, de lo que se trata aquí es de tomar en cuenta ambas esferas que han sido polarizadas y unirlas para realizar una síntesis en que ambas esferas sean complementarias y no excluyentes (en una superación dialéctica de ambas). Esto permitiría proponer una explicación de Chavín de Huántar en tanto formación económica social asimétrica estatal que es una forma universal pero reconociendo sus particularidades propias forjadas en una realidad concreta como la andina. En el mejor de los casos, se busca que esta propuesta sea heurística, proponiendo una metodología ad hoc y generando una discusión sobre las formas tempranas de institucionalización de la desigualdad social en los Andes prehispánicos.

Asimismo, la evidencia empírica desde los tiempos de la propuesta de Lumbreras ha crecido de tal forma que nos permitirá generar una síntesis arqueológicamente más informada. Es

12 Resulta interesante que casi al mismo tiempo, pero en Venezuela, Mario Sanoja e Iraida Vargas (1974) postulaban un "Modo de Producción Teocrático" (También ver Sanoja 1982: 227). Sin embargo, Ernesto Tabío (1978) criticó en su momento, este supuesto modo de producción pues sería inaceptable desde una perspectiva marxista-leninista (Dacal y Waters 2005:35). nuestro deseo que esta propuesta sirva para generar una línea de investigación que atienda, desde nuestra propia realidad, a fenómenos que se puedan estudiar y comparar universalmente, pero no desde afuera sino desde dentro de nuestra realidad. Además, aquí se hace la aclaración que dado que esto puede posibilitar una visión nacionalista y chauvinista de la arqueología que nosotros mismos hemos criticado anteriormente (Tantaleán 2008, 2010, también ver Burger 1992: 227) no es nuestro deseo explicar ese pasado desde la "peruanidad" sino más bien desde los Andes prehispánicos, un espacio geográfico y social amplio que trasciende y supera a las fronteras nacionales actuales.

\section{CONCEPTUALIZANDO Al ESTAdO TEOCRATICO ANDINO}

En primer lugar, un estado teocrático puede ser, como lo es posiblemente en los Andes y en otras áreas del mundo, una de las primeras formas de institucionalización de la desigualdad socioeconómica y sociopolítica. Aunque desde una perspectiva evolucionista parece que es la primera forma más extendida de la aparición de dichas desigualdades no es un camino que no pueda desandarse ni es una trayectoria social con rumbo definido, y por lo tanto, no es un requisito para el paso hacia otro tipo de sociedad más "evolucionada". Generalmente se asume que tras un estado teocrático, al complejizarse las relaciones sociales, especialmente las socioeconómicas, se daría paso a una sociedad de tipo estatal laica, secular o militarizada. A pesar que hay muchos ejemplos de ello (aunque por verificarse arqueológicamente en muchos casos) también existen numerosos contraejemplos, incluso en los Andes ${ }^{13}$. En todo caso, cuando algo de mayor "complejidad" o magnitud aparece esto deberá ser investigado como parte constitutiva o no de un mismo proceso histórico. Más aún, habría que ver sí la misma elite que generó lo anterior tiene relación con la subsiguiente generacionalmente hablando (acumulación de la

13 Por ejemplo, después de la ultima ocupación relacionada con el edificio en uso original de Chavín de Huántar viene la ocupación asociada al estilo cerámico Huaras (Rick et al. 2009: 103). 
producción social). Por ello, es necesario tener en cuenta que aunque el estado teocrático andino, como veremos aquí, es una forma original y tal vez "prístina" de estado en los Andes, este fue una manifestación que apareció en algunas áreas concretas coexistiendo con otras formas sociales que contribuyeron en mucho a su conformación o simplemente se mantuvieron expectantes y, en algunos casos, la rehuyeron o escaparon a su influencia o control directo, lo cual explica esos "vacios" en nuestros mapas arqueológicos durante la existencia de un estado.

De lo anterior se desprende que la formación estatal no puede o no debería verse como una forma mejor o más desarrollada de sociedad puesto que desde una perspectiva antropológica desde diversas tendencias teóricas (marxista, procesualista, postcolonial) esto supone la existencia de desigualdad social, el control de la mano de obra, la acumulación de excedentes, el control de la elite sobre la vida humana, etc. A pesar que los estados se relacionan y, sobre todo, los teocráticos que generan artefactos de gran calidad relacionados con materias primas exclusivas y una estética que la acompaña, tienen un logro artístico impresionante, hay que observar que estos objetos no se utilizan o consumen en todos los grupos sociales a los que pertenecería esta "cultura". De tal modo que este es un "arte" o producción social para la elite y que supone que su existencia o uso también supuso la inexistencia y no uso/consumo en otros contextos de la misma sociedad generando una distribución desigual de la producción social.

Asimismo, es necesario indicar que aunque parece existir un más temprano y único "origen" del estado teocrático andino, esto no significa que los demás hayan tenido que ver directamente con dicha primera aparición pues áreas diferentes tienen trayectorias sociales históricas diferentes. De hecho, como concebimos aquí la historia andina, la aparición del estado es consecuencia de una serie de factores, básicamente de las condiciones materiales históricamente constituidas, que son utilizados por un grupo de la sociedad (clase social) para establecer un lugar privilegiado en las prácticas sociopolíticas y socioeconómicas de la sociedad. Así pues, siempre que existan estas condiciones materiales puede o no generarse un estado, de tal manera que causalidad y casualidad están presentes en esta aparición del estado (un accidente histórico) y este se manifestará con características propias elegidas como estrategia por el grupo de elite para su reproducción. En este caso particular, analizamos las estrategias que están relacionadas con el uso de prácticas religiosas o socio ideológicas dominantes para generar y mantener la apropiación del trabajo o producto de este por el grupo de elite.

Así pues, los primeros estados teocráticos andinos al ya no estar vinculados con una fuerza evolutiva subyacente pueden aparecer y desaparecer en un área determinada con características similares o no pero siempre históricamente contingentes.

De este modo, en nuestra propuesta un estado teocrático andino es:

Estado: Porque supone la institucionalización de las desigualdades sociales (no su aparición, pues este puede ser un proceso previo) donde principalmente se da la estructuración de la sociedad en base a una división clara entre productores y no productores ${ }^{14}$. Un estado, así, supone la existencia de una contradicción objetiva entre dos grupos sociales antagónicos (clases sociales ${ }^{15}$ ) de los cuales uno domina y controla la producción y distribución de los bienes materiales (explotación). En este sentido, un estado no es una cuestión solamente cuantitativa (fe-

14 Como recientemente señala Millaire (2010a: 6186): "Las definiciones del estado son variadas, aunque la mayoría de los estudiosos está de acuerdo en que estas son organizaciones politicas por los que viven en estas como políticamente independientes y en las cuales los lideres especializados tienen la autoridad para controlar las actividades sociales, políticas, legales, económicas, y culturales, así como también el uso de la fuerza."

15 A pesar que investigadores como Richard Burger (1992: 181) y Luis Lumbreras utilizan el concepto de "clase social" para Chavín de Huántar, nosotros somos cautos en identificarlas como tales pues esta categoría marxiana fue definida en base a elementos objetivos de la sociedad capitalista y ejemplos conocidos por Marx y Engels en su tiempo. Si bien, nosotros creemos que en Chavín de Huántar y aun antes existirían clases sociales todavía deberemos estudiarlas de mejor manera para identificarlas arqueológicamente. 
nomenológica) o de complejización económica sino, sobre todo, es la consolidación sancionada y reproducida de una nueva organización de las relaciones sociales en las cuales un grupo minoritario de la sociedad se distancia de la producción básica (principalmente, de alimentos y medios de producción como la cerámica, textiles, instrumentos líticos, etc.) y se dedica a manipular, controlar y consumir el trabajo social de la población a la que tiene sujeta. Una forma de manipulación social en este contexto claramente surge de la religión.

TeOcRÁtico: porque las anteriores desigualdades sociales están originadas, mantenidas, controladas, normadas y justificadas institucionalmente mediante una práctica socio-ideológica llámese religión ${ }^{16} \mathrm{o}$ mito dominante que se practica y dirige ${ }^{17}$ como medio de reproducción de la asimetría social (sistema político y económico) y que tiene como objetivo concentrar productos mediante el monopolio del miedo o terror o la generación y ostentación de violencia fáctica y/o psicológica. De este modo, la religión subsume en sus narrativas las contradicciones objetivas de las clases sociales y se hace nece-

16 Para una discusión del uso del concepto "religión" en arqueología pero, sobre todo, de una critica al etnocentrismo de este concepto y su superación a través del reconocimiento de la existencia de religiones no relacionadas con la construcción del concepto a partir de la Europa de la Ilustración se puede consultar Insoll 2004: 13-16. También para Chavín de Huántar ver Rick 2005: 77 quien en su "modelo manipulador" recoge algunos conceptos marxistas sobre la religión.

17 Es importante señalar aquí que lo que se denomina especialistas religiosos es una denominación amplia que incluye a un grupo de individuos que están organizados políticamente y unidos por la actividad religiosa. De esta forma, aquí diferenciamos a los shamanes de los sacerdotes, pues estos últimos se acomodan mejor a la idea de especialistas que realizan sus prácticas dentro y mediante una institucionalización. Así, por ejemplo, Eller (2007: 72) señala que: "Uno llega a ser sacerdote por muy diferentes medios que por los que uno llega a ser un shamán. Comúnmente, la adquisición de un sacerdocio significa el dominio de un cuerpo de conocimiento y dogma, convirtiéndose en un "experto" en alguna ortodoxia (orto para "correcto/ verdadero" y doxa para "opinión"). Los individuos con ideas desviadas o "heréticas" no son buenos candidatos para recibir oficios sacerdotales; de este modo, los sacerdotes tienden a ser agentes conservadores. De hecho, ellos representan la institución a la cual ellos pertenecen, en lugar de ser "agentes libres" como lo son los shamanes." saria como medio de equilibrar y amainar las tensiones sociales que supone la existencia de la explotación, encubriéndola y haciéndola más dinámica, conformándose en el medio principal de control social. Por ello, sí existió algún cuerpo de guerreros este todavía no fue el principal grupo social ni dominó las relaciones sociales. En este contexto, el "Templo" o Centro Político Religioso $^{18}$, como preferimos denominarlo, es la principal propiedad de los teócratas y su instrumento de producción principal. Su defensa necesariamente supuso la existencia de un grupo de individuos afiliado a la elite que encontraba en la religión y en las armas la justificación de las propiedades de la elite.

A diferencia de los estados burocráticos que suponen la existencia de burócratas o especialistas políticos ("funcionarios") que reciben su manutención mediante dinero ${ }^{19} \mathrm{o}$ algún objeto que encarne un valor de cambio estandarizado y adjudicado por la institución política ${ }^{20}$, los teócratas o especialistas religiosos reciben su medio de vida en productos, en primera instancia, alimenticios y bienes básicos. De ello, se desprende que sus prácticas socioeconómicas son diferentes que las que se realizan dentro de sistemas monetarios donde el capital se acumula de otra forma y a otra velocidad. A pesar que la existencia de burócratas se ha propuesto para

18 Para una propuesta terminológica próxima a la nuestra pero para Cahuachi se puede consultar Llanos 2010.

19 Como señala el mismo Weber (1977[1922]: 22): "La evolución de la economía monetaria es un supuesto de la burocracia, ya que hay que compensar pecuniariamente a los funcionarios. En la actualidad no sólo prevalece este factor, sino que es la principal forma de compensación.". Incluso, cuando Weber se refiere a sociedades antiguas incluye las que poseían formas de retribución económica monetaria como el Egipto del Nuevo Imperio: "El prerrequisito normal para la existencia estable y continuada, e incluso para la instauración de administraciones burocráticas puras, es un cierto grado de desarrollo de una economía monetaria." (1977[1922]: 24).

20 De hecho, como el mismo Weber (1977[1922]: 4) aclara: "Tal como la hemos descrito, la burocracia sólo está del todo desarrollada en las comunidades políticas y eclesiásticas del Estado moderno; en el caso de la economía privada sólo lo está en las instituciones capitalistas más avanzadas. Una autoridad burocrática perdurable y pública, jurisdiccionalmente determinada, constituye normalmente una excepción y no una regla histórica". 
los Andes (por ej. Topic 2003) básicamente por las mismas funciones políticas que ellos parecen realizar (especialmente y según Weber, el "control de la información"), su origen y reproducción socioeconómica en la sociedad estatal andina no se ha explicado ${ }^{21}$.

ANDino: porque es una manifestación o fenómeno social con características locales (andinas) y que estaba basado en formas de producción también originarias dadas las condiciones sociales de la producción en el territorio andino. Dicha forma de producción andina tuvo un proceso histórico relacionado con los estados pero también independiente de ellos. En algunos casos, los estados asimilan dicha forma original de producción andina y las relaciones sociales que esta supone para su beneficio (por ejemplo, para época Inca, las relaciones sociales establecidas en el ayllu). Entender esta forma de producción y las relaciones sociales que estas suponen en la agricultura, el pastoreo, la caza, la pesca y/o la recolección es crítico para entender las particularidades de las sociedades andinas. Esto se hace necesario, sobre todo, desde una perspectiva arqueológica desarrollada desde una realidad centrada en los Andes que, en primer lugar, está basada en relaciones sociales sin la existencia de capital y donde la acumulación o retención del excedente se da en tributos de especies ${ }^{22}$ y la propiedad de la tierra, el principal medio de producción, cambió a lo largo de la historia. Según lo que planteamos acá, durante la existencia de los primeros estados teocráticos en los Andes, la propiedad de la tierra (hecha productiva) siguió en manos

21 Incluso, cuando se acepta la existencia de burócratas en sociedades estatales se señalan a partir del Horizonte Medio (por ejemplo, ver Isbell y McEwan 1991, Kolata 1993, Schreiber 1992) aunque para Topic (2003: 244) las verdaderas burocracias se encuentran en las fases tardías de la sociedad Chimú del Intermedio Tardío.

22 Según Lumbreras (com. pers. 2010) el estado teocrático andino estaría dentro de un "modo de producción tributario" aunque en este caso concreto es un tributo realizado en "ofrendas" (también ver Patterson 1991: 25). Es decir, el medio de producción principal de la elite es el "Templo" o "Centro Religioso-Político" para acumular la fuerza de trabajo materializada como productos finales o "ofrendas" que pueden ser alimentos, cerámicas, bloques líticos, etc. de los comuneros y, salvo las tierras sobre las que se asientan los Centros Políticos Religiosos y alrededores directamente relacionados, las demás tierras estaban fuera de su control directo. Adicionalmente, habría que explorar la cuestión del control de las fuentes de aguas (canales, bocatomas, manantiales, etc.) donde justamente, como veremos hacia el final, varios de los otros candidatos de Centros Políticos Religiosos ejercen un control espacial y suponían un control indirecto de la tierra agrícola que era beneficiada.

Asimismo, queremos detenernos en algo que nos parece clave para entender a los estados andinos pre-capitalistas y otros y que tiene que ver con que la producción no es individual sino más bien social o colectiva, situación que para tiempos prehispánicos incluso se observa hasta tiempos Incas, según las crónicas. Así pues, no podemos ver el trabajo de forma neoliberal pues los seres humanos del Formativo, como si se hace en contextos capitalistas, no pueden cambiar horas de su fuerza de trabajo por un salario. Por ello, si existió algún tipo de "pago" por parte de las elites hacia los constructores y artesanos ("peregrinos") de Chavín de Huántar este debió haberse dado de forma muy asimétrica, en el mejor de los casos mediante "pagos" en artefactos extraídos de la producción social también mediante ofrendas. Por ello, es necesario tomar en cuenta que los seres humanos que se acercan al sitio y los que no pero que comparten la producción de las ofrendas, están siendo consumidos, a través de la entrega de su trabajo social, en Chavín de Huántar ya que la producción es social. De todo esto se colige que las elites no consumen trabajo individual sino consumen trabajo social. Por consecuencia, las ofrendas de fuerza de trabajo o bienes no son una entrega individual sino que encarnan la producción social (también ver Mauss 1971[1924]:159). De este modo, la arquitectura de los edificios principales y las ofrendas que aparecen en los llamados "banquetes" no son entregas individuales sino que consumen el trabajo social de un grupo (dominado) a través de las elites de Chavín de Huántar o las elites locales "intermedias" que se acercan a Chavín. 
También, desde nuestra perspectiva, para que la aparición de grandes concentraciones de objetos y restos arqueológicos pueda ser consideradas y reconocidas como materializaciones de un estado, no nos detenemos exclusivamente en la constatación de dichas grandes acumulaciones de materiales arqueológicos (como puede ser las estructuras "ceremoniales" y/o urbanas) sino más bien en la investigación de las formas o mecanismos sociales por los cuales se generaron y mantuvieron dichas concentraciones de materiales arqueológicos. De este modo, el volumen arquitectónico solamente es una manifestación de una practica social extracomunitaria que debe estar generada por un grupo social que moviliza dicho traslado y concentración de objetos arqueológicos también extracomunitario. Sin embargo, esta misma consecuencia reflejada en la acumulación de materiales se puede conseguir, ya sea, mediante prácticas sociales colectivistas o comunitarias, es decir, realizadas y basadas en la decisión comunitaria o, más bien, generada por la decisión de una elite o grupo de personas dentro de la misma sociedad con un interés más bien particular.

Planteando de esta manera la ocurrencia de grandes volúmenes de materiales arqueológicos en un solo lugar y que suele ser visto automáticamente como la existencia de un estado, esperamos superar la clásica ecuación entre monumentalidad y estado, dejando para la investigación arqueológica las relaciones sociales materializadas en el territorio nuclear de la sociedad que alberga dicho monumento. En ese sentido, también, hay que señalar que en muchos casos los sitios que reconocemos como parte principal y asentamiento de esos grupos sociales beneficiarios de la producción social son el palimpsesto de una acumulación histórica de materiales que pueden abarcar varios cientos de años y que, obviamente, comenzaron posiblemente como pequeños edificios dentro de relaciones comunitarias pero que en un momento histórico fueron "secuestrados" o apropiados por un grupo social que los hizo suyos.

Para nosotros el mejor candidato para un estado teocrático andino sigue siendo el Chavín de Huántar del primer milenio antes de nuestra era y del cual, además, poseemos una mayor cantidad de datos arqueológicos recuperados sistemáticamente y fechados radiocarbónicos suficientes como para darle una temporalidad consistente a las manifestaciones arquitectónicas y artefactuales allí concentradas. Aunque dicho trabajo arqueológico acumulado en el sitio no está exento de discusión (por ejemplo, ver Kaulicke 2010) vemos esta situación de manera optimista (en una superación dialéctica) y que, aparejado al desarrollo de cronologías absolutas (tecnológico), también necesitamos generar teorías sociales (epistemologías) que expliquen este fenómeno mediante metodologías desarrolladas para contextos arqueológicos andinos: una cronología absoluta que no se contraponga a una explicación social informada teóricamente no mejorará nuestra comprensión de Chavín de Huántar u otros fenómenos "Formativos".

Asimismo, como vimos arriba, pese a que para Luis G. Lumbreras $(1974,1993)$ Chavín de Huántar era la concreción de un primer Estado Teocrático en esta zona y Richard Burger (1992: 181, Burger y Matos 2002: 171) lo reconoce como un estado para época Janabarriu, por lo general, se prefiere dejar de lado su definición sociopolítica (por ejemplo, ver Conklin y Quilter 2008: xxviii), aceptándose como mucho la existencia de una "autoridad" o una "desigualdad social" (Rick 2008). En otros casos, se trata de explicar al sitio funcionalmente o por la consecuencia en el área y otras alejadas como un fenómeno social dejándose de lado la estructura social que la soporta y le da sentido y dinámica al sitio: falta proponer quienes serían los agentes que originan todo este movimiento social. De este modo, se ha generado toda una literatura sobre Chavín de Huántar que lo homologa con un "centro ceremonial" (Rick 2006) u "oráculo", obviamente, modelos basados en el sitio del Pachacamac de la época de contacto conocido por fuentes etnohistóricas que ya habían asumido dicha función para el sitio (Burger 1992: 193, 2008: 681). En otros casos, aunque en la misma senda, se habla de Chavín de Huántar como la sede de una "Con- 
federación” o "Amfictyonía”23 (Makowski 1997: 516), donde los diferentes grupos sociales que componen esta confederación (especialmente, sus elites) se encuentran para re-generar sus vínculos y realizar grandes banquetes o fiestas. Nosotros no negamos que todas esas prácticas ceremoniales, oraculares o festivas se hayan podido dar en el sitio de Chavín de Huántar. De hecho, la materialidad social asî lo sugiere (Lumbreras 1993:351, Burger 2008:

23 Una anfictionía es la confederación, liga o reunión política de ciudades-estados o poleis para sostener un culto religioso centrado y encarnado en un Santuario, Templo principal u Oráculo como el más célebre de Apolo en el Delfos de la Grecia Arcaica, ya consolidado desde el Siglo VIII a.C. y que permaneció vigente hasta, por lo menos, el IV a.C. (Lane Fox 2007: 91). Sin embargo, sobre todo para su época de mayor esplendor, las relaciones sociales allí estaban basadas en la existencia de la moneda que, si bien, se podría originar como forma de ofrenda o tributo a los dioses y a los encargados del Santuario, tiene su génesis en la entrega al santuario de especies con valor socioeconómico y sociopolítico (también ver Mauss 1971[1924]:181). Así pues, la moneda en la anfictionía griega tenía como objetivo sustituir a las ofrendas en especies para pasar a la circulación y acumulación más rápida de riqueza encarnada en objetos más pequeños aunque de difícil obtención como el oro o la plata pero aún conservando esa faceta religiosa de la cual se generó. De hecho, la anfictionía délfica termina acuñando sus propias monedas aunque bajo el control de la autoridad de las poleis (Domínguez Monedero 2002) y sustentada económicamente por sus aristocracias (Lane Fox: 2007: 92). Como Domínguez Monedero (2002: 233) señala: “... la conclusión que parece imponerse es la de que existe una estrecha relación entre la moneda en Grecia y el ámbito de lo religioso, tanto en los inicios mismos de la moneda como en la relación entre la moneda y los santuarios. Los templos y santuarios griegos, como depositarios del gran número de riquezas que la piedad de sus fieles acumulaba en ellos, tenían la obligación de protegerlas y custodiarlas, retirándolas en principio de la circulación. Desde muy temprano esas ofrendas han sido objeto de cuantificación por los sacerdotes, que han establecido su valor empleando los sistemas de pesos y medidas ya acreditados, lo que ha permitido desde siempre conocer su valor real; la aparición de la moneda no ha hecho sino simplificar estas valoraciones, que siempre fueron de interés para los santuarios y el propio valor nominal y simbólico que tendrá la moneda desde su inicio la hará también un artículo idóneo para ser ofrecido en los santuarios.". Por todo lo anteriormente señalado, la analogía de las anfictionías griegas con Chavín de Huántar nos parece inadecuada puesto que el tipo de relaciones socioeconómicas y sociopolíticas de la antigua Grecia estaban basadas en la moneda y las aristocracias de las poleis que la controlaban.
688). Sin embargo, lo que nosotros queremos explicar es cómo un sitio del volumen, longevidad y hegemonía como Chavín de Huántar se origina, construye y, sobre todo, como se mantiene socioeconómica y sociopolíticamente "desde dentro" para luego proyectarse hacia las elites de menor rango y comuneros, a través también de esos banquetes vinculados con la "ostentación", la "competencia" o la "reciprocidad asimétrica" pero que solo representarían una externalización de prácticas sociopolíticas y socioeconómicas más profundas centradas y desarrolladas en Chavín de Huántar. En suma, nos interesa conocer la estructura económica y política que le dió sustento a la elite de Chavín de Huántar que debe tener necesariamente una manifestación objetiva y concreta más allá de las percepciones subjetivas que podrían haberse generado de cara a la sociedad y que son muy difíciles de evidenciar y mucho menos valorar cuantitativamente en el presente.

En nuestro caso, hemos elegido generar una representación arqueológica de lo que es Chavín de Huántar entre otras muchas que existen y que tiene un linaje teórico que se puede consultar en otros lugares (Carneiro 1970, Haas 1982, Lull y Micó 2007, Makowski 2008a, Tantaleán 2008) y que detallaremos más adelante, aunque antes de hacer eso tendremos que ubicar espacial y temporalmente a Chavín de Huántar en los Andes centrales.

\section{Chavin de Huántar: un estado teocrático andino en el Callejón de Conchucos}

Chavín de Huántar es un sitio arqueológico enclavado en un valle interandino de la cordillera de los Andes a unos 3150 msnm, en una gran cuenca interandina que se conoce popularmente como el Callejón de Conchucos, en la actual provincia de San Marcos del Departamento de Ancash. El sitio descansa sobre una pequeña terraza aluvial justamente en la confluencia de los valles del rio Wacheqsa y Mosna, este último que dirige sus aguas hacia el gran río Marañón (Fig. 1). 


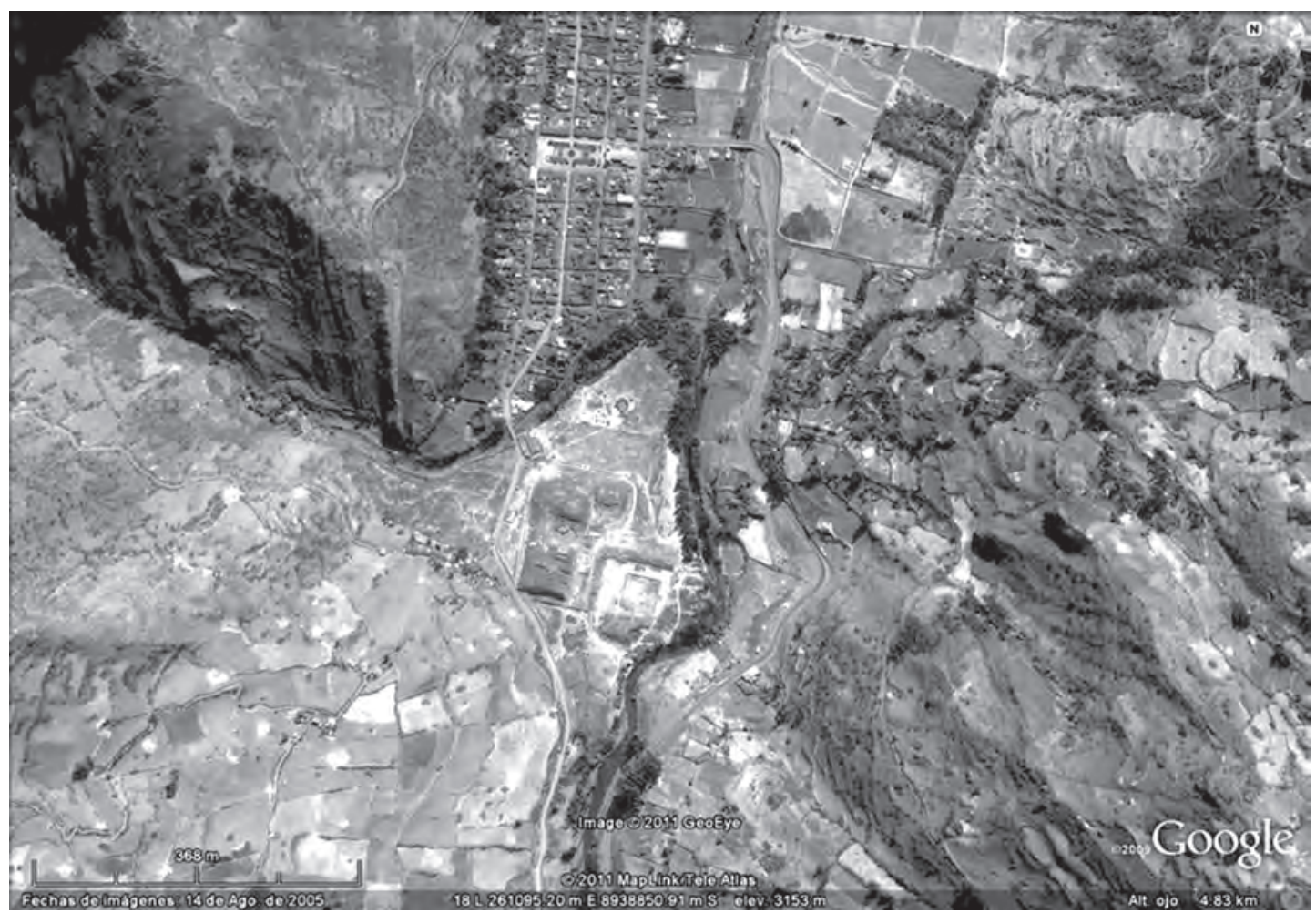

Figura 1: Vista satelital del área de Chavín de Huántar donde se aprecia la confluencia de los ríos Mosna y Wacheqsa, el área de los edificios principales y la población actual de Chavín de Huántar

Desde su descubrimiento arqueológico 24 por el investigador peruano Julio C. Tello (1919), Chavín de Huántar (1200 a.C.-500 a.C. ${ }^{25}$ ) ha despertado gran interés por su carácter monumental y por las representaciones iconográficas relacionadas con esta y los objetos que se adscribieron a dicho sitio. Gracias a este interés también motivado por haber sido definido como la "cultura matriz de la civilización andina"

$24 \mathrm{El}$ sitio era conocido desde la época colonial y fue visitado por numerosas personas entre los que destacan Pedro Cieza de León (1553), Antonio Vázquez de Espinoza (1616), Eduardo de Rivero y Ustariz (1841), Antonio Raimondi (1873), Charles Wienner (1880), Ernest Middendorf (1893), Toribio Polo (1900), etc. (Kauffman 1963: 23, Lumbreras 1993: 49, Mesía 2007).

25 Para este trabajo se toman como referencia los fechados radiocarbónicos publicados en Rodríguez Kembel 2008: 72 y su correlación con los fechados por luminiscencia ópticamente estimulada (OSL) de Feathers et al. 2008. Finalmente se toman en cuenta los fechados publicados en Rick et al. 2009. una serie de investigadores como Wendell C. Bennett (1939), John Rowe (1962), Luis Lumbreras (1966-1967), Rosa Fung (1973-1974), Richard Burger (1975-1976) y Federico Kauffmann (1980-1982) han realizado una serie de investigaciones en torno a este sitio y su carácter social. Recientemente, desde 1995 hasta la actualidad, el equipo de John Rick de la Universidad de Stanford que, también, incluye arqueólogos peruanos, ha realizado un trabajo de largo aliento que ha generado una nueva cantidad de datos y revisado la cronología del sitio mismo (Rick et al. 2009). Así, ahora se sostiene que ya no solamente el núcleo monumental se dividió en las dos grandes fases arquitectónicas planteadas por John Rowe ("Templo Viejo" y "Templo Nuevo") sino que, al menos, existirían 5 grandes fases constructivas (Rodríguez Kembel 2008). De esta forma, tenemos un mejor conocimiento del desarrollo del sitio durante el tiempo de su uso original. Así, relacionándolo con las fases 
cerámicas planteadas inicialmente por Richard Burger (1998) tenemos que la fase se correspondería con las fases "NEA" y "Expansión" (1200. 800 a.C.) y la Janabarriu y Ofrendas con la "Fase Negro y Blanco" ("Black and White Stage") (800 a.C. -500 a.C.) para finalmente tener una fase de remodelación menor conocida con el nombre de Soporte ("Support") (ver Mesía 2007 y Rick et al. 2009 donde, además, se hace una crítica a las fases cerámicas propuestas por Burger). Finalmente, después de su uso original este sitio, como ya había observado Tello, los edificios principales son cubiertos por estructuras domésticas asociadas con el estilo cerámico "Blanco sobre Rojo" o "Huaras".

Una cosa que si es importante señalar es que el sitio de Chavín de Huántar, dado el lugar en el cual se encuentra, tiene diferentes problemas de conservación de las evidencias arqueológicas sobre todo condicionadas por el "dinamismo geomorfológíco" del área que supone un gran movimiento de tierras (Contreras 2007), un fenómeno que, por ejemplo, se pudo patentar en el conocido aluvión de 1945 que cubrió gran parte del sitio (Kauffman 1993, Lumbreras 1993:54). Así, en la actualidad, para llegar a los depósitos "Formativos" es necesario profundizar un promedio de 4 metros (Contreras 2007: 20).

Asimismo, la ocupación moderna del pueblo de Chavín de Huántar e infraestructura como la carretera antigua que pasa detrás del edificio principal ha alterado la visibilidad de las evidencias arqueológicas. Pese a lo anterior, es posible aun reconocer restos significativos para emprender una explicación sociopolítica del sitio por medio de excavaciones arqueológicas (Fig. 2).

\section{INDICADORES ARQUEOLÓGICOS, MATERIALIDAD SOCIAL Y PRÁCTICAS SOCIALES}

Pese a que existe una extensa literatura relacionada con el tema del estado (Childe 1950, Flannery 1998, Service 1984[1975], Haas 1982, Renfrew y Bahn 1998, Marcus y Feinman 1998: 6, Adams 2001, entre otros) donde se pueden reconocer los indicadores arqueológicos universales del estado prehistórico, muchas veces nuestra concepción y reconocimiento del estado resulta siendo más antropológica, sociológica o filosófica que arqueológica ${ }^{26}$. Como veremos en esta sección, se proponen ciertos indicadores eminentemente arqueológicos para explicar su pertenencia a ciertas prácticas sociales que sugieran una sociedad de tipo estatal teocrático andino tal como definimos aquí para Chavín de Huántar. Estos indicadores son propuestos tras la revisión de la literatura existente en la actualidad ${ }^{27}$ y nuestras propias observaciones. Estos indicadores no deber ser tomados como una lista acabada ni mucho menos se debe tomar al pie de la letra sino que más bien se deben tomar como una "hoja de ruta" para poder generar metodologías ad hoc cada vez más ajustadas para contrastar nuestra teoría con la realidad del fenómeno social generado en Chavín de Huántar.

Como se verá más adelante, muchos de estos indicadores están interrelacionados y muchos de ellos pueden aplicarse a otros casos, aunque como se verá la inexistencia de algún indicador secundario (indicadores del 14 al 16) no invalida su identificación como Estado Teocrático Andino. Asimismo, es necesario reconocer que la cuestión de la magnitud o cuantificación de ciertos indicadores es una cuestión que se deberá valorar local o regionalmente puesto que no son indicadores comparables entre regiones o tiempos debido a la propia trayectoria histórica de generación de dichos estados teocráticos en cada área y tiempo. Sin embargo, hemos tratado de ordenar estos

26 Por ejemplo, como recientemente señala Millaire (2010a: 6186) en un artículo enfocado en el surgimiento del estado en la costa norte del Perú: "Los estados son arqueológicamente visibles a través de una cantidad de indicadores materiales, incluyendo un sistema de asentamiento de cuatro niveles, evidencia de trabajos defensivos y expansión, templos y palacios, recolección de tributo y sistemas de redistribución, y producción artesanal especializada (Spencer y Redmond 2004, Flannery 1998, Wright 1977, Billman 2002).". Como allí se puede ver casi todos sus indicadores de estado no son directamente arqueológicos sino más bien teóricos extraídos de otras realidades históricas (salvo el caso de Billman) y, especialmente los últimos, basados en planteamientos antropológicos económicos.

27 En un esfuerzo de síntesis y desde su perspectiva, Rick (2006:204) propone unos "parámetros determinantes de un centro ceremonial", algunos de los cuales coinciden con nuestros indicadores aquí presentados. 


\section{Chavín de Huántar - Sectores del sitio}

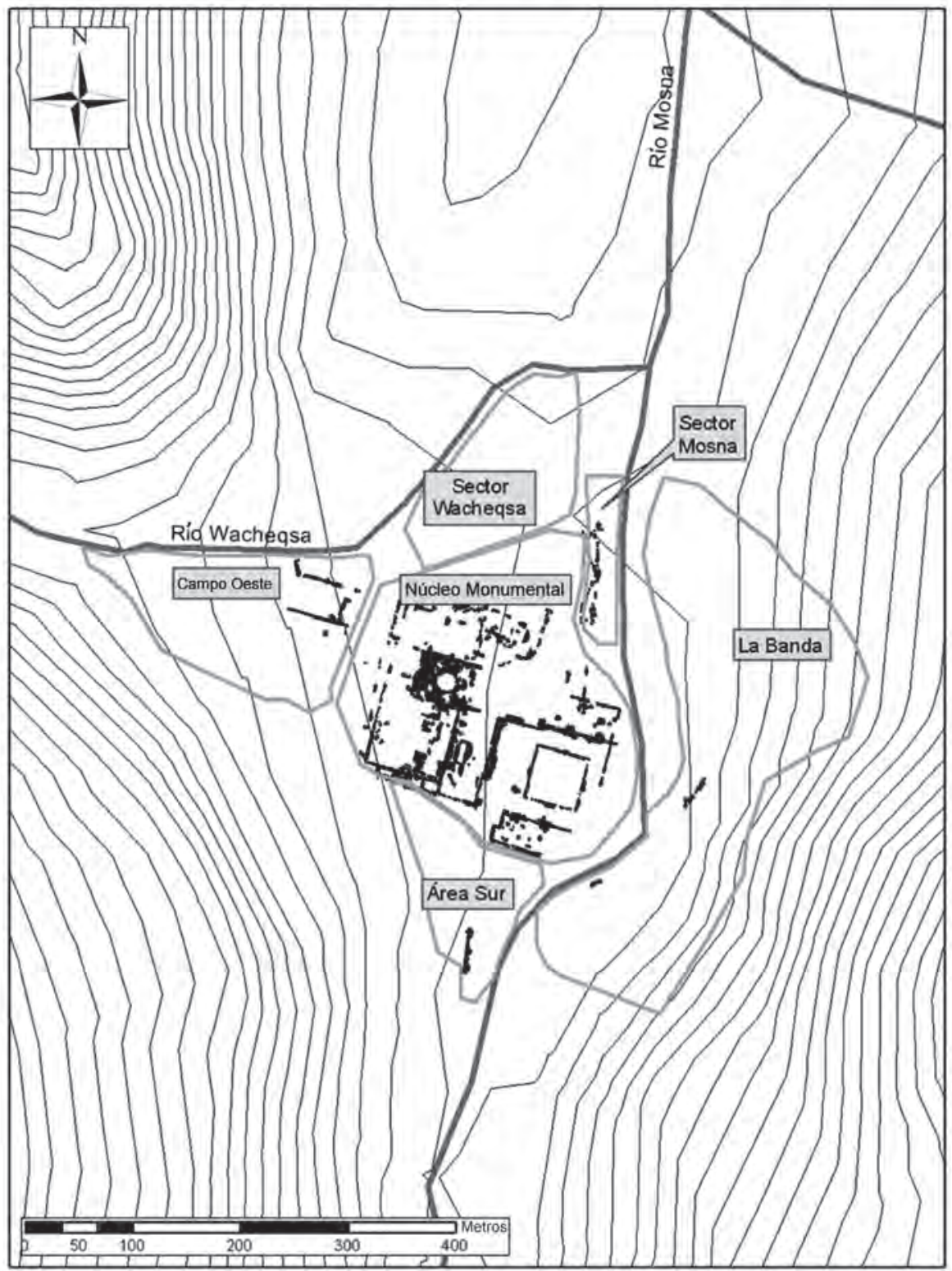

Intervalo de lineas de contorno: $10 \mathrm{~m}$

- Arquitectura de sitios

\section{Sectores de sitios}

Figura 2: Sectores principales del sitio de Chavín de Huántar (según Contreras 2007: Fig. 1.3) 
indicadores jerárquicamente de tal modo que los primeros 13 indicadores deberían ser vistos como requisitos para la existencia de un estado teocrático andino aunque los restantes tres harían más consistente su existencia a un nivel regional. Con respecto a esta última cuestión, creemos que el modelo más cercano para la territorialidad de los primeros estados teocráticos andinos más allá del sitio mismo (lo que se conocen como "estados territoriales") estaría más cercano a lo que se conoce en otras partes del mundo como "ciudad-estado"28 (Yoffee 2005: 44, Smith y Schreiber 2006: $7^{29}$ ). En cualquier caso, nosotros nos inclinamos a pensar en un territorio discontinuo, como el que se ha evidenciado, incluso, para estados más tardíos y con mayor capacidad coercitiva en los Andes prehispánicos (Stanish 2003). No obstante, esto lo veremos en su momento y ahora pasemos a desarrollar nuestros indicadores arqueológicos que deberían existir en un Estado Teocrático Andino, focalizado en un Centro Político Religioso como Chavín de Huántar:

\section{Indicadores arqueológicos en el área de edificios principales}

1. Ubicación espacial privilegiada del asentamiento.

2. Principal concentración de volúmenes arquitectónicos de la región.

3. Prolongado desarrollo arquitectónico y de ocupación.

4. Utilización en los edificios principales de diseño, estructuras y/o elementos arquitectónicos relacionados con fenómenos celestes y/o naturales

5. Existencia en los edificios principales, de formas arquitectónicas, elementos arquitectónicos y artefactos pre-existentes en el mismo sitio y tomados de otras áreas cercanas o lejanas.

28 Si bien, recientemente Burger (2008: 697) identifica al Chavín de Huántar de su fase Janabarriu con una "pequeña ciudad-estado" también lo homologa con una "Jefatura compleja".

29 También ver Millaire (2009: 10, 2010b) para una propuesta de "ciudades-estados" para Gallinazo y Moche.
6. Existencia de espacios arquitectónicos abiertos y cerrados en el área de los edificios principales.

7. Existencia en diferentes soportes (arquitectura y objetos) de representaciones iconográficas complejas principales con rasgos antropomorfos en el área de los edificios principales.

8. Evidencia de cuerpos humanos mutilados, asesinados (sacrificados), consumidos y representaciones de actos violentos realizados por entidades antropomorfas, y representaciones de armas en los edificios principales.

9. Existencia de espacios de concentración de objetos muy elaborados y estandarizados en los edificios principales producidos fuera de la región.

Indicadores arqueológicos en las áreas asociadas directamente a los edificios principales

10. Existencia de áreas "domésticas" o "laborales" asociadas directamente con los edificios principales del sitio.

11. Existencia de artefactos estandarizados producidos en el sitio en los edificios principales y en el área inmediata

12. Estructuras arquitectónicas domésticas contruidas con materiales y tecnología de mayor calidad.

13. Acumulación de artefactos estandarizados producidos localmente y no, solo en algunos contextos domésticos afuera de los edificios principales del sitio.

\section{Indicadores arqueológicos en las áreas alejadas del centro político religioso y zona residencial de Chavín de Huántar}

14. Existencia de asentamientos monumentales que repiten el diseño y técnica y relacionados con materiales originales del sitio estudiado.

15. Existencia de artefactos de la misma morfología e iconografía fuera del sitio estudiado, especialmente en otros contextos de "elite". 
16. Existencia de asentamientos domésticos alejados pero relacionados directamente con el sitio estudiado.

A continuación nos detendremos en la materialidad social ${ }^{30}$ de cada uno de estos indicadores arqueológicos en Chavín de Huántar para su definición como estado teocrático andino. Para cada indicador proponemos prácticas sociales que habrían producido esas materialidades sociales según nuestra perspectiva y, en algunos casos, ampliándola más allá de Chavín de Huántar y su entorno inmediato.

\section{Indicadores arqueológicos en el área de edifi- cios principales}

\section{Ubicación espacial privilegiada del asentamiento}

\section{Materialidad social}

Chavín de Huántar se encuentra en la convergencia de los valles Mosna y Wacheqsa, siendo el primero el valle principal del área, puerta de entrada al Callejón de Conchucos. La misma ruta que viene desde el Callejón de Huaylas cruzando las montañas y llega hasta el sitio con su parte final en el rio Wacheqsa también puede haber sido importante en el pasado como ruta de comunicación de estas dos importantes regiones. Por lo tanto, como varios investigadores han señalado (Burger 1992, Lumbreras 1993: 50), Chavín de Huántar se convirtió en un "nudo de caminos" que articuló las "regiones orientales de Huánuco, el Alto Huallaga y la cuenca del Marañón y, a través de esta vía, la Amazonía; los valles altoandinos de la región Nor Central y Norte que conducen a la cuenca de Cajamarca y, desde allí, a la Costa Norte y a los valles de La Libertad y Lambayeque; cruzando hacia el Oeste las dos cordilleras, se puede acceder a las cuencas de los valles de Casma o, más al sur, a las de los ríos Fortaleza, Pativilca y Huaura que dan acceso hacia los valles de Lima". (Canziani 2009:124).

30 Seguimos la definición de Vicente Lull (2008: 128): "La materialidad social alude a los materiales resultantes del devenir social y a lo que ese devenir encerró en ellos. Constituye la concreción de toda la materia social en juego. En ella caben desde las ideas y las palabras que se realizaron hasta los recursos que instituyeron ideas que, a su vez, se concretaron luego en materia social."
En los Andes, como los del área montañosa en cuestión, estos ríos son las rutas naturales hacia diferentes espacios ecológicos principalmente hacia la vertiente oriental de los Andes. Resulta importante señalar que Chavín de Huántar está ubicado en la parte superior de un rio que desemboca en el rio Marañón, esa zona de la cual se extraen algunas ideas para varios iconos incluidos en su religión (indicador 7).

Asimismo, a pesar que es un área muy poco productiva agrícolamente hablando, esta fue profundamente modificada tanto para la construcción de las edificaciones como para reconducir el agua de los rios Mosna y Wacheqsa (Burger 1978, Rick 2008). Esto habría mejorado la producción agrícola del área aunque el mayor volumen de alimentos procedería de otros lugares, como veremos más adelante. Aparejado a esto estaría también la propuesta de que las aguas ya canalizadas del Wacheqsa recorrerían un circuito dentro del edificio principal de Chavín que ofrecerían un potente efecto sonoro (Lumbreras et al. 1976) (ver indicador 6). Además, es importante reconocer que el sitio mismo se halla a la sombra de un cerro que no pasa desapercibido en esta zona del valle y desde Chavín de Huántar se puede llegar a alcanzar lugares donde existe visibilidad de algunas montañas nevadas (Reinhard 1985). Los mismos afloramientos rocosos de cuarcita detrás de los principales edificios de Chavín, también marcan claramente un lugar significativo en el paisaje (Rick 2008: 8).

Además, como veremos en el punto sobre arqueoastronomía (indicador 4) el edificio principal goza de una buena disposición con respecto a la observación de astros, especialmente el sol.

\section{Prácticas sociales implicadas}

Claramente, Chavín de Huántar se encuentra en una ubicación estratégica relacionada con una ruta importante (aunque no la única) hacia la ceja de selva y costa (Canziani 2008: 124) y con espacios altamente productivos agrícolamente y, posiblemente, con un importante cerro que también puede ser utilizado como cantera. Así, pues, Chavín de Huántar, como muchos otros sitios importantes prehistóricos en el mun- 
do se halla en un lugar históricamente señalado como lo son encrucijadas de caminos o rutas de acceso a diferentes regiones ecológicas o espacios productivos.

También, Chavín de Huántar puede estar asociado directamente a "monumentos naturales" como cerros con dimensiones, conformaciones o colores especiales y que, por lo tanto, destacan en el paisaje. De la misma forma, puede estar ubicado en partes significativas o relevantes de los valles como, por ejemplo, el lugar donde este se origina o estrecha.

Esta ubicación podría ofrecer al sitio y sus ocupantes un acceso privilegiado a recursos altamente productivos o muy escasos en la zona (recursos agrícolas, pastoriles, pesqueros, fuentes de minerales, rocas o arcillas). Claramente existiría una ventaja de entrada en la ubicación o génesis, o crecimiento de un sitio arqueológico que es usufructuada por un grupo social con la capacidad de mantener un flujo constante de personas, dada su ubicación pero que puede ser ampliada al generar otros medios más allá de la simple ruta de intercambio o paso hacia otra zonas ecológicas. Lo anterior es significativo en un área como los Andes donde los espacios ecológicos son tan contrastantes y ofrecen una diversidad de recursos que en principio pueden ser intercambiados libremente pero que con la aparición de un control de una ruta ubicando un Centro Político Religioso puede generar una forma diferente de relacionarse con el espacio y las personas que circulan por allí, controlando su movimiento.

\section{Principal concentración de volúmenes arquitectónicos de la región}

\section{Materialidad social}

El volumen de estructuras arquitectónicas de Chavín de Huántar es, de lejos, el mayor de toda la zona del callejón de Conchucos para su tiempo de uso original el que, además, se daría sobre todo en el lapso de unos 700 años (Rick et al. 2009: 113) (Figs. 3 y 4). Sobre todo, llama la atención la capacidad para poder movilizar grandes cantidades de rocas y tallarlas, algunas de ellas traídas de canteras alejadas (como el granito blanco) para la construcción y embellecimiento de los principales edificios. Con relación a esto, Richard Burger (2008: 683) calcula que esta "arquitectura pública" alcanzaría las 10 hectáreas. Además, como Rick (2008) plantea, un trabajo de desvío del rio Mosna y movilización de material para nivelar dicha área ganada al cauce del rio y para manejar otros posibles riesgos como aluviones (Contreras 2007), un trabajo que también fue reconocido y registrado por Tello (1960: Lam. XLV, XLVI, XLVII). Con relación a todo este trabajo, Daniel Contreras (2007: 224) plantea que el volumen de piedras y tierra movidas para construir las estructuras arquitectónicas y algunas modificaciones del paisaje asociadas a Chavín de Huántar alcanzaría $\operatorname{los} 450,000 \mathrm{~m}^{3}$.

\section{Prácticas sociales implicadas}

Tradicionalmente la arquitectura monumental ha sido el indicador más utilizado en los Andes para definir la existencia de un estado. Sin embargo, como mencionábamos arriba esta ecuación monumentalidad=estado es demasiado mecanicista para ser aceptada a priori. Asimismo, debemos indicar que las concentraciones de estructuras arquitectónicas a lo largo del tiempo no necesariamente significan que estas se generaron por medio de la coerción física o religiosa.

Sin embargo, visto en el contexto de la región y del momento histórico, tal despliegue en una época donde las fuerzas productivas y los medios de coerción fáctica no parecen estar muy desarrollados, la existencia de tal monumentalidad y volumen de objetos y arquitectura conformarían la materialización de una inversión de trabajo social que claramente va más allá de un trabajo colectivo o comunal y/o espontáneo y que estuvo dirigido a la generación de un espacio planificado dentro de un diseño bastante definido (indicador 3).

Para ello, el único motivo que podemos plantear más allá de la voluntad o fé de los participantes en la creación de dicho sitio y su mantenimiento es la religión (ver indicadores 7 y 8) utilizada para generar y enfocar dicho tra- 


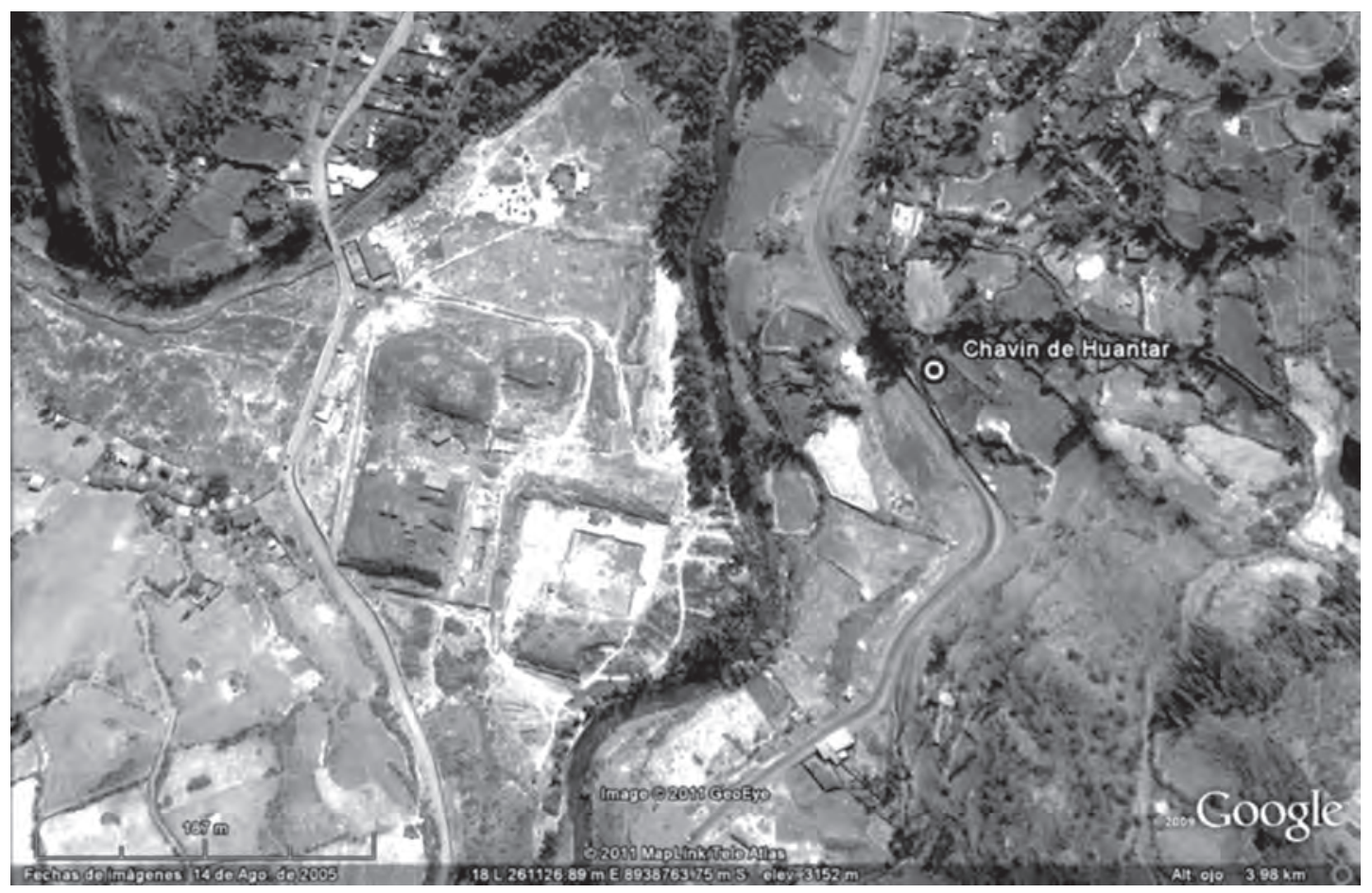

Figura 3: Vista satelital donde se aprecia el área de los edificios principales de Chavín de Huántar

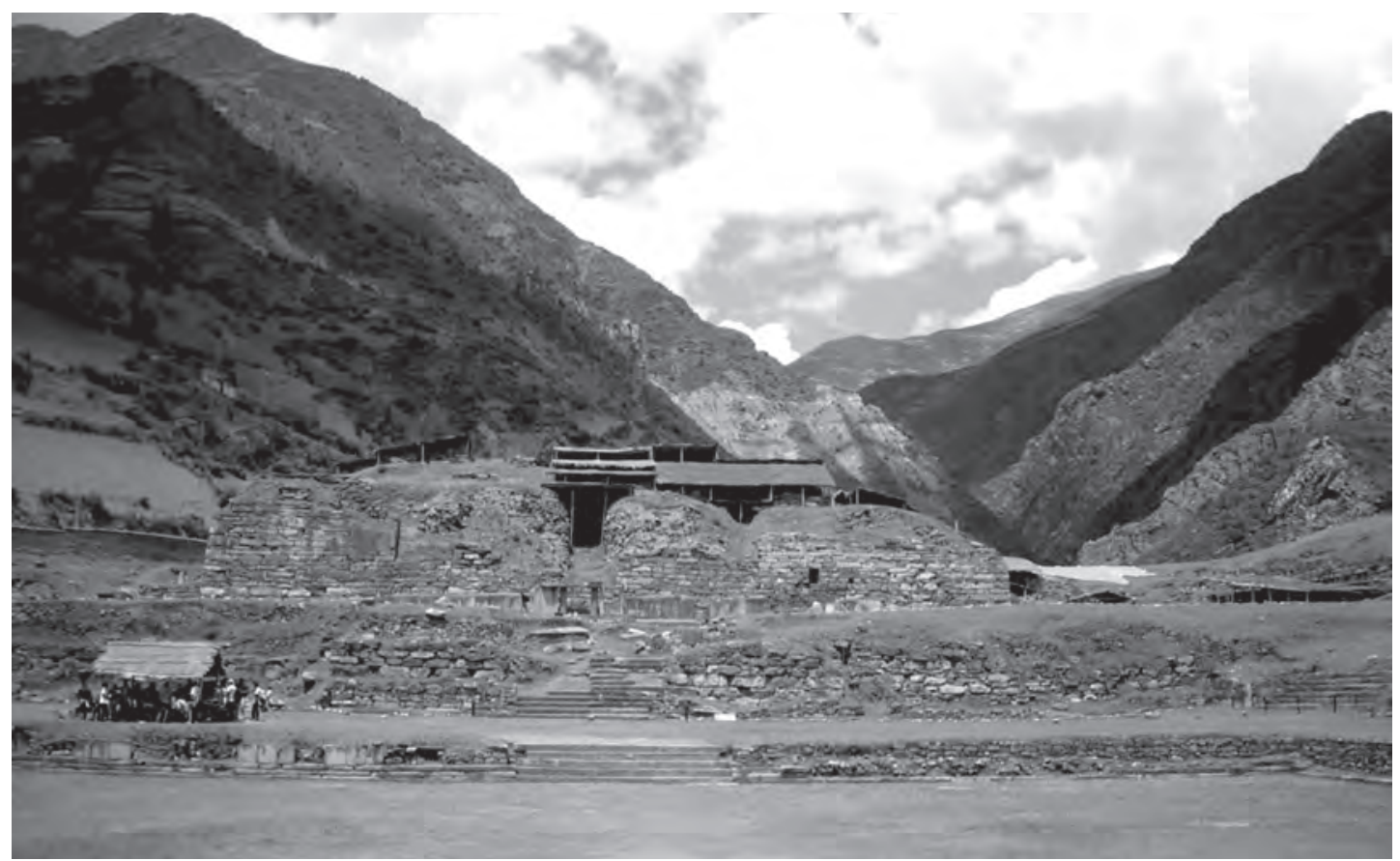

Figura 4: Vista desde la plaza cuadrangular de los edificios principales de Chavín de Huántar. Sobresale el "Templo Nuevo". Al fondo se aprecia el valle del Wacheqsa (foto del autor) 
bajo social hacia un objetivo concreto y dirigido (para luego ser administrado exclusivamente) por los líderes de Chavín de Huántar.

De la misma forma, como hemos visto y atendiendo a una configuración de un estado teocrático este no debe compararse con otras concentraciones tempranas en otras partes del mundo en cuanto esto primero corresponde con una forma de producción original en los Andes. Aquí se hace hincapié en el hecho que, por lo general, se han querido comparar a las concentraciones de arquitectura monumental con la ciudad del Viejo Mundo, especialmente la occidental, lo que ha generado su aceptación o rechazo como indicador de la existencia de un estado prehistórico.

Para nosotros, la concentración de estructuras arquitectónicas monumentales supone un indicador importante pero que debe estar articulado y contrastado con otros indicadores arqueológicos para reconocer a dicha acumulación de estructuras arquitectónicas monumentales como parte importante de una sociedad con sujetos alejados permanentemente de la producción material. En ese sentido, mucho se ha hablado, sobre todo desde la perspectiva childiana o inspirada en el materialismo histórico, que una característica principal (económica, antropológica) de un estado es la acumulación de excedentes en dichos centros políticos religiosos. Para ello, en primer lugar, debemos atender a que los excedentes se materializan y se extraen de la sociedad en diferentes formas, todas ellas constituidas históricamente. De esta manera, los excedentes pueden estar materializados, para el caso de los estados teocráticos andinos, en la misma construcción y mantenimiento del sitio o en prácticas que no han dejado evidencia. Aun así, se espera encontrar espacios o depósitos que contengan la acumulación de artefactos, objetos o materiales que están por encima de los que posee una unidad domestica del área o que son extraídos de fuentes o producidos en otras regiones (ver indicadores 9 y 15).

Se espera por tanto que dicha acumulación sea la única o la más importante en una región amplia que puede ser un valle o una sección de este, pues si conviviese con otros esto no signi- ficaría la concentración de poder político, religioso y económico del centro político religioso. Esto más bien correspondería a algo que se ha venido definiendo como heterarquía o simplemente "grupos corporativos sin autoridad centralizada" como los que se plantea para la "cultura Manchay" (Burger 2008, 2010).

\section{Prolongado desarrollo arquitectónico y de ocupación}

Materialidad social

Como se puede ver en los trabajos de Tello (1943), Rowe (1967), Lumbreras (1993), Kauffman (1993), Burger (1992, 1998), Rodríguez Kembel (2005) y Rick (2005, 2008), el sitio atravesó por una serie de cambios a lo largo del tiempo, lo cual significa que este tuvo un uso prolongado independientemente de la discusión acerca de la antigüedad del inicio de este proceso. Ese tiempo de construcción de los edificios principales es calculado por Rick y asociados (2009: 113) en unos 700 años aunque este lapso de tiempo puede ser algo mayor. Igualmente, es importante reconocer que durante varios siglos un "patrón básico" fue mantenido en la construcción a pesar de las nuevas adiciones y modificaciones del edificio original: una suerte de plan maestro concebido inicialmente y que fue mantenido durante gran parte de la vida útil de dicho edificio.

\section{Prácticas sociales implicadas}

Un indicador arqueológico importante y relacionado con el anterior en tanto indicador de estado es que estos centros políticos religiosos deben haberse mantenido en uso durante largos periodos de tiempo (a menos que hablemos de "estados fallidos" (Patterson 1991: 26)). Con ello se aprecia que este sitio ha tenido un éxito en reproducirse a sí mismo, generando incluso un desarrollo arquitectónico con una trayectoria propia pero que incluiría otros elementos foráneos (indicador 5). Sin embargo, hay que hacer la advertencia que esto requiere poseer una historia bastante detallada del sitio puesto que hacia el final del uso de este sitio tenemos 
una acumulación de diferentes estructuras que no necesariamente fueron sincrónicas. Por ello, re-conociendo las fases constructivas amarradas a fechados radiocarbónicos podremos reconocer la temporalidad en el uso de todo el sitio o solamente sectores en este.

Esto significa que la elite que controló el sitio pudo mantener y ampliar su importancia para la población local y extralocal, materializando el excedente del trabajo de estas personas en dicho proceso de construcción y mantenimiento del sitio.

También es necesario señalar, siempre bajo la perspectiva anterior, que mucho de lo primigenio del sitio podría estar relacionado con una sociedad aun no estatal pero que, en algún momento de su historia, cambia su uso hacia prácticas sociopolíticas que habrían comenzado comunitarias pero que devinieron en particulares ${ }^{31}$. Estas últimas, según su éxito, generalmente se asociarán con grandes proyectos de remodelación, reconstrucción del sitio que supone el consumo del trabajo de los individuos sujetos a este sitio político-religioso. Así pues, este indicador supone la reproducción exitosa del estado teocrático, es decir, el éxito de las prácticas sociopolíticas asimétricas. Por lo general estas remodelaciones o adiciones arquitectónicas suponen el paso y la generación de espacios abiertos o inclusivos hacia espacios cerrados o exclusivos (ver indicador 6).

\section{Utilización en los edificios principales de diseño, estructuras $y / o$ elementos arquitectónicos relacionados con fenómenos celestes y/o naturales}

\section{Materialidad social}

Como varios investigadores (Lumbreras 1993: 353, Milla Villena 2008: 278, Rick 2008) han señalado, los edificios principales de Chavín de Huántar están orientados a líneas de recorrido del sol y están alineados con el movimiento de ciertos astros. Esto, obviamente, supone un con-

31 Si uno debería elegir ese momento para Chavín de Huántar este estaría más vinculado con el estilo cerámico Janabarriu de Burger o con la "Fase Expansión" de Kembel. trol y registro de dichos movimientos celestes para su uso por los especialistas en actividades y trabajos que necesariamente suponen una calendarización o para generar información con respecto a los ciclos agrícolas, tan importantes en una zona, como el Callejón de Conchucos (y otras áreas cercanas), donde la producción principal de alimentos es la agrícola. La orientación del diseño de los principales edificios de Chavín de Huántar, la inclusión de plazas circulares hundidas, ejes de los edificios, orientaciones de las galerías, tendría sentido solamente con respecto al seguimiento de trayectorias celestes desde estos edificios principales. De hecho, el objeto principal del Templo Viejo, el "Lanzón monolítico" o "Gran Imagen", a pesar que se encuentra internado en el corazón del edificio "mira" hacia la salida del sol mediante la galería y una abertura en el frontis que conecta con el exterior ${ }^{32}$. Finalmente, no podemos dejar de señalar a la gran roca tallada conocida como "Choque Chinchay" que se ha relacionado con la posible observación de estrellas, posiblemente las que para nosotros componen la constelación de las Pléyades (Lumbreras 1970: 83, Burger 2008: 688).

\section{Prácticas sociales implicadas}

La utilización de diseño, estructuras y/o elementos arquitectónicos relacionados con fenómenos celestes y/o naturales es importante en la misma configuración de los espacios arquitectónicos y elementos que integran los edificios principales de Chavín de Huántar y de otros muchos casos precedentes (indicador 5), contemporáneos y posteriores. Dado que el conocimiento de las condiciones climáticas es importante para el mundo andino, estos espacios construidos al contener dichos "aparatos de medición del tiempo y condiciones meteorológicas" se convierten en instrumentos de producción de los encargados del Centro Político Religioso, siendo aquellos elementos que pueden ser utilizados por ellos para generar una acumulación de ese mismo conoci-

32 Sin embargo, hay que anotar que la posición en la que encontramos a este objeto en la actualidad es en gran parte debido a su recolocación por Marino Gonzáles (Rick y Mendoza 2003: 22). 
miento que luego será utilizado para extraer objetos y fuerza de trabajo de otros miembros de la sociedad que se acerquen a dicho espacio arquitectónico. Asimismo, en tanto religión que está asociada con potencias naturales, divinidades $\mathrm{o}$ fuerzas desconocidas (indicador 7 y 8), los sistemas de medición de estas fuerzas naturales serán importantes para generar y mantener esa religión o ideología que está monopolizada y recreada por los dirigentes del sitio. De este modo, los miembros de la elite son especialistas en el control del conocimiento pragmático que se torna o camufla en lo religioso, lo cual resulta valioso en un mundo donde las condiciones climatológicas o los desastres naturales conviven con los grupos sociales sujetos a estos estados teocráticos.

\section{Existencia en los edificios principales de formas arquitectónicas, elementos arquitectónicos y artefactos pre-existentes en el sitio y tomados de otras áreas}

\section{Materialidad social}

Como muchos investigadores han señalado (por ejemplo, Burger 2008, Lumbreras 2007) el sitio de Chavín de Huántar constituye una síntesis de diferentes fórmulas arquitectónicas desarrolladas previamente en lugares como la costa norte o la costa central e, incluso, como postula Kembel (2008) de tradiciones religiosas tempranas como las de Kotosh, cuestión que además parece haberse constatado en el sector del "Campo Oeste" donde se ha encontrado una estructura tipo Templo Mito (Contreras 2010).

De esta manera, los constructores de Chavín de Huántar utilizaron ciertas formas y elementos arquitectónicos de sitios que ya habían obtenido éxito previamente como lugares de reunión o culto apropiándose de dicho trabajo acumulado y reuniendo en el seno del sitio diferentes tradiciones dentro de su propio espacio para generar y reproducir un discurso religioso amplio pero ahora administrado permanentemente desde un solo lugar y por un grupo de individuos. Formas arquitectónicas como los edificios con planta en U, las pirámides truncas, las plazas rectangulares y circulares hundidas son importantes en tanto su reunión en un solo sitio como Chavín de Huántar
Además, aparejada a la arquitectura están la litoescultura y las representaciones iconográficas (indicadores 7 y 8) que aparecen sobresalientemente en los elementos arquitectónicos de los edificios como columnas, dinteles, umbrales, cornisas, lajas, etc. Adicionalmente, vale la pena mencionar que Lumbreras (1993: $58,61)$ encontró indicios de posibles decoraciones de barro pintadas de colores que cubrirían paramentos de los edificios principales. Como muchos investigadores han señalado (Bischof 1985, 1997, 2008, Lumbreras 1993: 61, Pozorski 1983: 36) estas representaciones se originan en otras áreas geográficas como la costa norte, norcentral o central, siendo Chavín de Huántar un receptor de muchos de dichos elementos iconográficos. La recreación, reciclaje o re-significación de dichos iconos en otros temas más complejos, ahora utilizados por los constructores de Chavín, supone un manejo hábil y significativo de tradiciones anteriores.

\section{Prácticas sociales implicadas}

Como varios investigadores han señalado (Burger 1992, Lumbreras 2007), la arquitectura de Chavín de Huántar en tanto morfología, diseño y contenido fue mayormente dependiente de desarrollos externos al Callejón de Conchucos. De esta forma, se puede reconocer que temas y elementos iconográficos se han materializado en la construcción de Chavín, asegurando su éxito en un nuevo contexto merced a su arraigo en tradiciones religiosos más antiguas. Sin embargo, hay que tener en cuenta que en Chavín de Huántar estas formas arquitectónicas y representaciones iconográficas son re-producidas para justificar un nuevo contexto socioeconómico y sociopolítico de tal forma que, a pesar de guardar similitudes con sus predecesores, ahora en conjunto conforman la materialización de un nuevo discurso justificador que se recrea a través de las prácticas sociales que le acompañan y le dan sentido en ese espacio social.

Asimismo, en Chavín de Huántar como en otros varios sitios de la misma categoría, en tanto centros políticos religiosos, existe un objeto principal que reúne la esencia del sitio y alrede- 
dor del cual se organizan los demás elementos e, incluso, los demás edificios y espacios abiertos del complejo (indicador 6). Este elemento puede haber sido originado o utilizado en el sitio tempranamente y se mantiene a lo largo de la existencia del mismo y dicha profundidad histórica le confiere ese halo mitológico y fundacional del sitio. Creemos que este objeto principal sería el "Lanzón monolítico". Hasta este, generalmente, solo llegan los individuos que están relacionados directamente con el control y mantenimiento del sitio y otros que están reproduciendo el culto local o foráneamente, especialmente otras elites regionales. De igual modo, alrededor de este objeto principal se pueden hallar otros objetos secundarios (en especial "proyecciones" del original) pero que pueden revestir importancia dentro del discurso religioso político generado por la elite que controla el sitio y gestiona los recursos que llegan motivados por el objeto principal. Además, de dicho discurso religioso, el discurso político puede generar la afirmación por medio de la antigüedad o la ancestralidad materializada en dichos objetos del grupo dirigente que se genera un linaje o genealogía mitológica que puede hundir sus inicios en las profundidades del tiempo. Por ello mismo, hasta los propios cuerpos de los ancestros pueden ser los objetos principales o estar asociados a este.

\section{Existencia de espacios arquitectónicos abiertos y cerrados en el área de los edificios principales}

\section{Materialidad social}

Chavín de Huántar se distingue por tener una gran cantidad de edificios que demarcan, establecen o delimitan espacios abiertos y cerrados. Hablamos de espacios abiertos especialmente de las plazas como las del Templo Nuevo y los espacios alrededor de las edificaciones principales como el mismo atrio del Templo Nuevo y el atrio y plaza circular del Templo Viejo. Sin embargo, ahí ya tenemos una jerarquía de espacios pues en el caso de la plaza cuadrangular del Templo Nuevo este podría albergar a unas 1000 personas mientras la plaza circular del Templo Viejo solamente podría contener a unas 100 personas (Burger 2008: 693). De este modo, a medida que uno se interna en el sitio se hallan espacios arquitectónicos cada vez más reducidos desde la misma plaza circular hundida hasta las mismas galerías internas de los edificios piramidales como las asociadas con el subsuelo de las áreas frontales del Templo Viejo y Nuevo (Rick 2006: 204).

\section{Prácticas sociales implicadas}

Como espacio creado para administrar el trabajo de otros, la convocatoria y la consecuente reproducción de prácticas religiosas suponía la existencia de espacios arquitectónicos en los cuales se reunía a grupos de personas, en este caso las plazas como la cuadrangular del Templo Nuevo y lugares desde los cuales se dirigían rituales o se colocaban objetos de indudable valor simbólico para la gente que asistía a Chavín de Huántar (Rodríguez Kembel 2008). De hecho, en el lugar de Chavín de Huántar y a través de su proceso constructivo se generaron espacios sociales inclusivos pero también más exclusivos, estos últimos enfocados en el principal elemento lítico de todo el sitio: el Lanzón monolítico, uno de las pocas piezas que se halla en su espacio original (aunque ver nota 33) y que según los estudios arqueológicos e iconográficos estaría al comienzo de la secuencia de construcción de Chavín de Huántar. Estos espacios exclusivos hacen evidente que existe una propiedad de dichos espacios asumido y mantenido por las elites de Chavín de Huántar.

De este modo, en Chavín de Huántar se construyeron grandes espacios donde se reunió una gran cantidad de personas y en los que, desde los edificios que tienen cierta preponderancia, por su volumen, dentro del espacio importante, se realizan puestas en escena o representaciones ("performances") de los mitos o prácticas religiosas relacionadas con el culto principal y/o accesorios. En estas representaciones, la elite juega un rol preponderante pues son ellos los que hablan por medio de sus dioses o fuerzas naturales a la gente allí reunida. Además, dado que este sistema está basado en la posibilidad de ejercer o controlar la violencia o las fuerzas naturales, es el lugar elegido para ejercer una presión psicológica o mantener el discurso que se dirige a la población de 
una forma bastante evidente. Incluso, serían los espacios donde también se podrían realizar sacrificios humanos o simulaciones del mismo con el objetivo de hacer patente la capacidad de los encargados del sitio para realizarlos. En última instancia, lo que se trata es de mantener vivo y reproducir el sistema teocrático mediante la realización de representaciones o performances que, además, incluyen artefactos (ver indicadores 9 y 13) y arquitectura realizada para tal caso.

Asimismo, existen otros espacios más reservados donde se realizan prácticas socioideológicas y/o sociopolíticas más reservadas, casi siempre ubicadas en el interior de los grandes edificios del sitio. Casi toda la literatura arqueológica coincide en señalar que Chavín de Huántar fue la residencia de especialistas en prácticas de exaltación de la psiquis, estados alterados de la conciencia, incrementos de las percepciones, experiencias e iniciaciones "shamánicas" que tomarían lugar, sobre todo, dentro de espacios cerrados como las galerías de los edificios principales de Chavín de Huántar. Sin embargo, a esto habría que agregar, por supuesto, que estas prácticas "shamánicas" ya no se dan de forma gratuita o abierta ${ }^{33}$ sino más bien que se realizan especialmente de forma exclusiva o elitista por individuos altamente especializados y distanciados socioeconómica y sociopolíticamente del resto de la sociedad y que estarían más cercanos a sacerdotes ${ }^{34}$ que a los shamanes y que realiza-

33 Como se puede esperar en una comunidad donde el shamán no se enriquece o empodera políticamente a través de su práctica y que es la figura etnográfica siberiana original de esta idea de los shamanes y otras áreas (Eliade 1987, Price 2001, Morris 2006: 16, Eller 2007:72).

34 Esta diferenciación también es establecida en la antropología de la religión: "En el pensamiento convencional, el sacerdote hace muchas cosas que no hace un shamán. Élo ella es a menudo un especialista a tiempo completo ocupando el "oficio" formal de sacerdote logrado mediante el estudio, comprobación y "ordenación" por una institución o estructura religiosa con el poder y autoridad para investir sacerdotes." (Eller 2007:73. Trad. nuestra. También ver Morris 2006: 18, Winkelman 2010: 57). Resulta también interesante que para Jerry Moore (2005: 220) los shamanes se relacionarían con arquitectura de "viviendas, áreas de baile públicas o las casas de los hombres" mientras que los sacerdotes ("canonists") "estaban asociados con templos, adoratorios y otras arquitecturas sagradas." rían su actividad posiblemente a cambio de objetos de gran valor económico (indicador 9) y ya no de forma altruista o desinteresada.

\section{Existencia en diferentes soportes (arquitectu- ra y objetos) de representaciones iconográficas complejas principales con rasgos antropomorfos en el área de los edificios principales}

\section{Materialidad social}

En el sitio de Chavín de Huántar lo que más ha llamado la atención es su "arte" o representaciones iconográficas en diferentes soportes, especialmente el asociado con la arquitectura (Tello 1960, Rowe 1967). Independientemente de cómo se las interprete, en estas representaciones, claramente se nota que la mayoría de las representaciones están antropomorfizadas y, de hecho, las principales escenas, temas o entidades están realizando actividades humanas y que tendrían relación estrecha con las acciones llevadas a cabo en el mismo sitio (Lumbreras 1993: 60). Entre la escultura, el "Lanzón monolítico", además de estar ubicado en un espacio más que exclusivo, con sus $4.5 \mathrm{~m}$. de altura y su compleja decoración es el más sobresaliente y que reúne en sí mismo, como objeto y representación, el centro del sitio (Fig. 5).

Otros objetos como el Obelisco Tello (Fig. 6), incluso, han suscitado interesantes aproximaciones a la interpretación de la ideología, religión o cosmovisión que se produjo y reprodujo en Chavín de Huántar (Tello 1923, Rowe 1967, Roe 1974, Lathrap 1982, Curatola 1991, Campana 1995, Makowski 1997, Vargas 2005, Bischof 2008, etc.). No cabe duda que el sitio de Chavín de Huántar fue el principal repositorio de la época en cuanto a objetos líticos con representaciones más complejas en la sierra norcentral, con cerca de 200 litoesculturas (Burger 2008: 683), incluyendo otras piezas tan emblemáticas como la estela Raimondi, las Columnas Blanca y Negra del Templo Nuevo, la Cornisa de las Falcónidas, y las Cabezas Clavas ${ }^{35}$, por

35 Lumbreras (2007: 197) suma alrededor de $105 \mathrm{ca}$ bezas clavas recuperadas en el sitio de Chavín de Huántar pero calcula que habrían existido en total unas 150 de ellas, las cuales se hallarían empotradas en las paredes exteriores, principalmente del Templo Nuevo y Viejo. 
mencionar solo a las más conocidas. De hecho, se puede reconocer que la litoescultura y la lapidaria no están aisladas sino que más bien conforman, a lo largo de generaciones, la materialización de un conjunto de prácticas socioideológicas o rituales que cobran sentido en la arquitectura y el espacio que se constituyen de cara a los grupos de individuos que se acercan a Chavín de Huántar.

\section{Prácticas sociales implicadas}

De todos los artefactos de Chavín de Huántar, de lejos, el "Lanzón monolítico" es el que mayor peso tiene y alrededor del cual parecen girar los demás artefactos (el "objeto clave o primordial" según Lull 2007), seguido por una serie de objetos líticos que encarnan las ideas y temas más importantes que se quieren trasmitir a los asistentes a Chavín de Huántar. Resulta interesante en este contexto que, a pesar que se ha notado una complejización mayor de los temas en dichas piezas, la serie litoescultórica parece comenzar con una entidad antropomorfa e, incluso, en las fases más tardías se siguen acompañando a estos con seres antropomorfos.

De lo anterior, también se puede desprender que en estas representaciones iconográficas ${ }^{36}$ se están reproduciendo en piedra a las actividades llevadas realmente en el sitio mismo y, posiblemente, las realizadas por los dirigentes del sitio o sus seguidores allí reunidos. Esto afirma la capacidad de los dirigentes del sitio para originar y mantener una religión importante en la cual los seres naturales o

36 Pese a que en las últimas dos décadas se ha dado un incremento significativo de estudios iconográficos en el área andina prehispánica también estamos de acuerdo con la crítica que se hace al método iconográfico inspirado en Erwin Panofsky (por ejemplo ver Victorio 2009: 55, siguiendo a Kubler 1999 [1962]: 447) básicamente porque en dicho método se hace necesario contar con fuentes literarias y poseer, para llegar al nivel iconológico, es decir del discurso o temas tras los íconos, un conocimiento de la mentalidad de la época de la producción de los iconos. Generalmente, esta comprensión de las mentalidades se ha dado asumiendo que la mentalidad andina ha sido inmutable y que los ejemplos etnográficos o antropológicos de épocas históricas encierran esencias transhistóricas que se pueden volcar a las representaciones iconográficas prehispánicas, desconociendo la producción y uso histórico de dichas representaciones. sobrenaturales se han encarnado en formas humanas, un correlato del poder de los seres humanos en el mismo sitio de Chavín de Huántar.

Este es uno de los indicadores arqueológicos más evidentes aunque indirectos de la existencia de un estado teocrático andino. Es indirecto por-

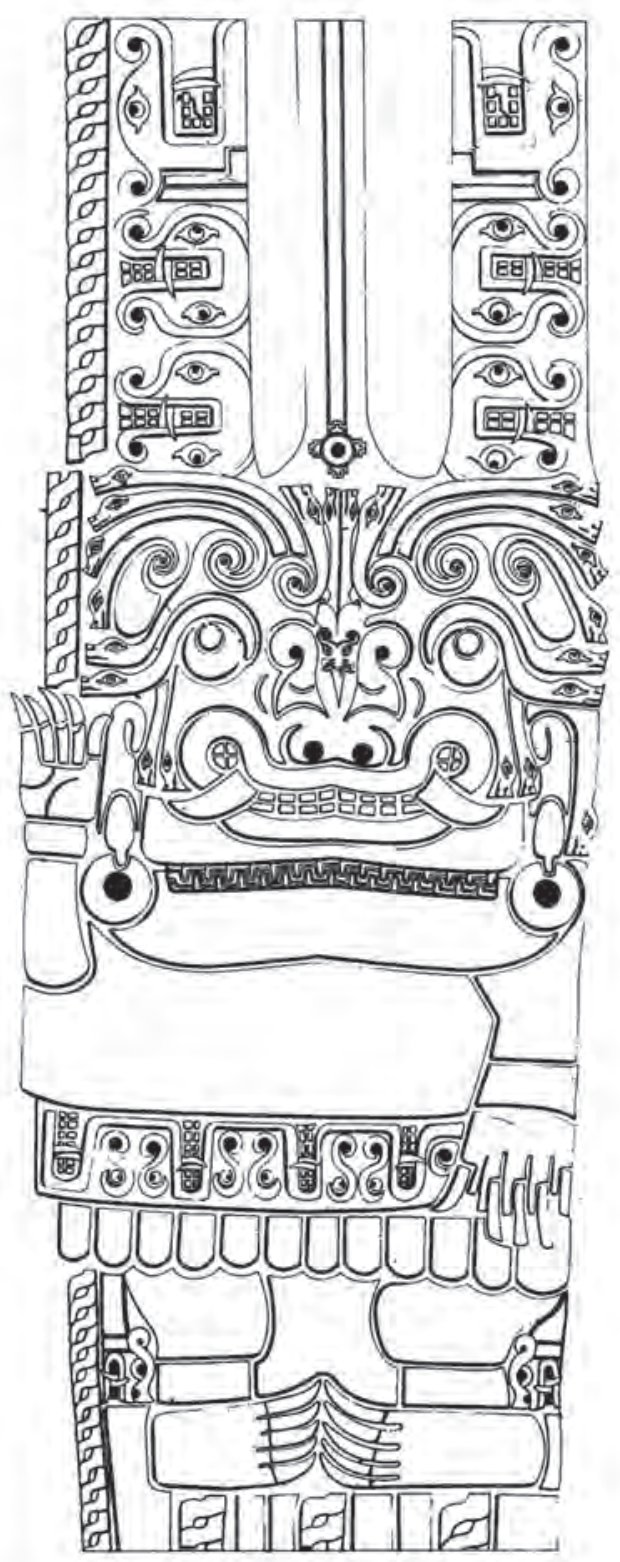

Figura 5: Desarrollo del Lanzón monolítico según Burger 2008: Fig. 35.8 

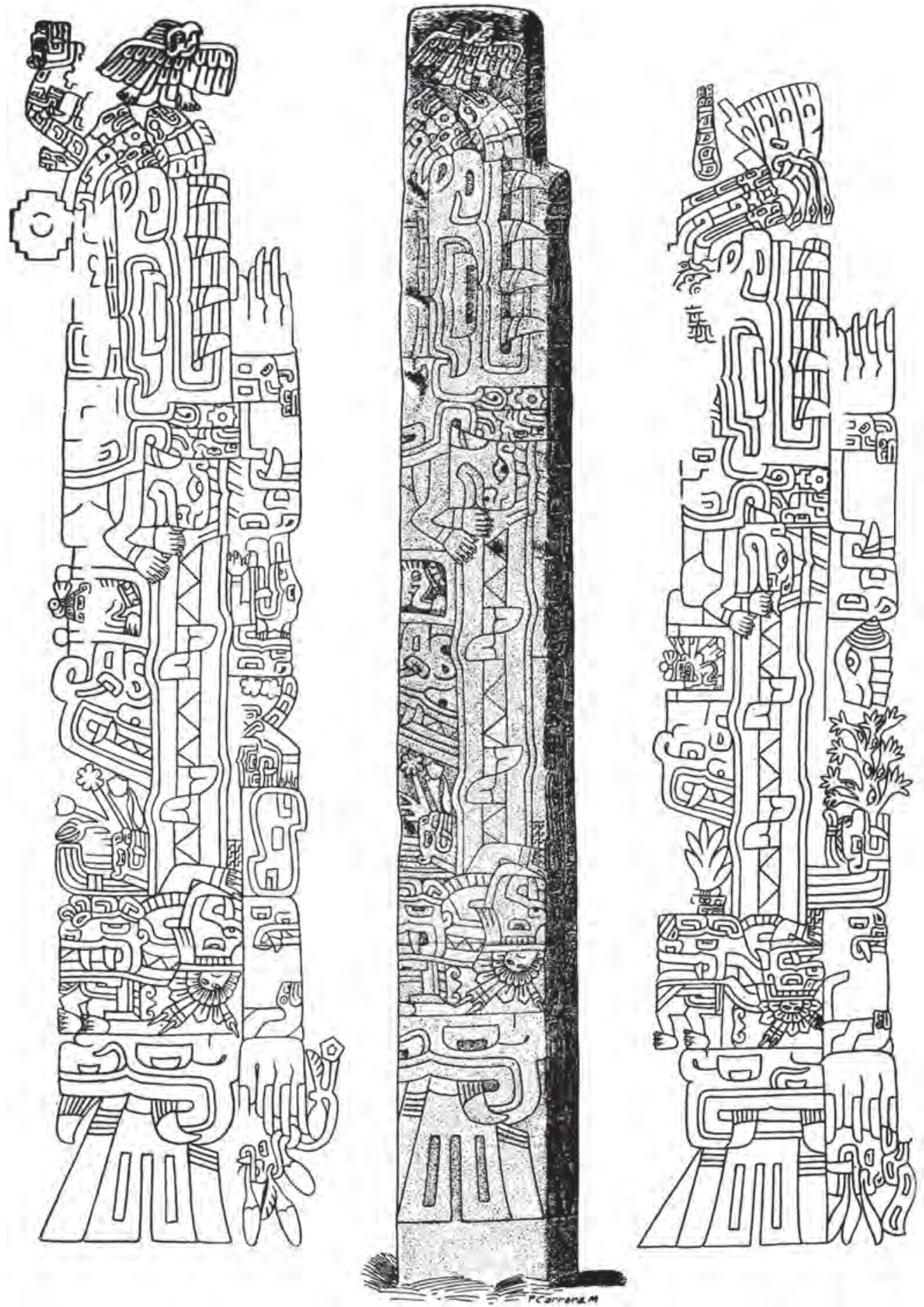

Figura 6: Obelisco Tello (según Tello 1960) 
que está basado en la representación de un cuerpo de seres o entidades que reflejan la existencia de un sistema de creencias organizado, producido y reproducido por los dirigentes del centro político religioso. Claramente estas entidades pueden encajar dentro de lo que se podría denominar una religión ya que su estandarización y reiteración en diferentes soportes supone que estas creencias se encuentran institucionalizadas a pesar que hayan podido ser retomadas de cultos previos (iarcaísmos?) o inspiradas en otras creencias mitológicas de otros tiempos o áreas geográficas. El shamanismo, como practica ritual original y principal en sociedades cazadoras-recolectoras o comunitarias en la que los estados alterados de la conciencia y la curación juegan un rol primordial (Winkelman 2010: 51, 56), claramente ha sido incorporado en esta religión y materializado en diferentes soportes (litoescultura, cerámica y textiles) pero ahora con el objetivo de darle contenido y dinamismo a la religión oficial de Chavín de Huántar.

De este modo, estas representaciones iconográficas reflejarían a nivel de las prácticas socioideológicas, la existencia de sujetos que han asumido el rol del control, manejo o interpretación de las potencias o fuerzas naturales (idivinidades?). Estos seres, al tomar forma humana, describirían que los especialistas religiosos han creado un discurso en el cual las entidades naturales o sobrenaturales han adquirido forma humana siendo, a su vez, un correlato de su propio poder concreto en este mundo pues ellos son los encargados de administrar realmente dicho sitio y como veremos en el indicador 8 hasta de quitar la vida humana. En este sentido, la religión se convertiría en una "tecnología del poder" y objetos, como el "lanzón monolítico", serían "armas" que ejercen la violencia de forma indirecta. De esta manera, la religión encarnada en el "templo" se convierte en el medio de producción principal de la elite en el estado teocrático andino.

\section{Evidencia de cuerpos humanos mutilados, asesinados (sacrificados), consumidos y repre- sentaciones de actos violentos realizados por entidades antropomorfas y representaciones de armas en los edificios principales}

\section{Materialidad social}

Durante las excavaciones de Richard Burger de los años 1975 y 1976, en los alrededores del edificio principal de Chavín, este investigador localizó en su unidad B1-7 "cuatro calaveras humanas que probablemente fueron dejadas como ofrendas durante la construcción" de una plataforma asociada con cerámica de su fase Urabarriu (Burger 1978: 297). Asimismo, durante las excavaciones de Luis Lumbreras en la "Galería de las Ofrendas" asociada a la terraza de la plaza circular hundida, este investigador realizó el hallazgo de fragmentos de huesos humanos de, al menos, 8 individuos que tras un análisis bioantropológico le indicaron el consumo de partes anatómicas humanas y que postuló como un "canibalismo ritual" (Lumbreras 1993, Baraybar 1993). De este modo, es posible que o bien estos "sacrificios" se dieron en el mismo sitio o se realizaron muy cercanamente puesto que estas partes humanas, para ser consumidas, debieron de haber estado en buen estado de conservación.

También, Cisneros y Lumbreras siguiendo una ilustración de John Rowe (1967: fig. 20) determinan que existen representaciones humanas que bien podrían encarnar a especialistas guerreros (También ver Tello 1960: fig. 82, Burger 1992: fig. 162). En ese mismo sentido, recientemente Rick (2008: 21) ha reconocido en una cornisa lítica la representación de sujetos asociados a armas, lo cual supone la existencia de un grupo de personas vinculadas directamente con la elite de Chavín que también portaban $\operatorname{armas}^{37}$. Ya, en 1980 Cisneros y Lumbreras nos acercaban a la problemática de un cuerpo especializado en la violencia, lo cual permanecía aún elusivo para ellos. Estos investigadores re-

37 Dichas armas no serían de una gran sofisticación como se ve en toda la época prehispánica y que pueden ser tan simples como hondas y piedras arrojadizas, porras, lanzas, flechas. Asimismo, la obsidiana que es utilizada para puntas y cuchillos de gran calidad aparecen en diferentes contextos asociados con Chavín de Huántar (Burger et al. 1998) y lugares relacionados con este. Incluso, se podría decir que las relaciones entre Chavín de Huántar y el sitio de Atalla tenían como uno de sus objetivos principales el acceso a la obsidiana (además del cinabrio) extraída de la cantera principal más cercana de este mineral, ubicada en Quispisisa, Huancavelica (Burger 1992: 212, Burger y Matos 2002: 173). 
conocían que "los restos arqueológicos de Chavin nos dicen que la religión tenía una función represiva y agresiva muy fuerte; los dioses chavinoides no son personajes pacíficos, ni mucho menos. Una buena hipótesis sería el proponer, como explicación, que los chavinoides tuvieron una organización que sin desarrollar aun la guerra plenamente, sus efectos fueron suplidos por una religión que exigía sacrificios humanos, tales como cabezas trofeo y toda una complicada liturgia." (Cisneros y Lumbreras 1980: 265. También ver Verano 2001: 167). Así pues, si bien el medio principal de ejercer el control sobre los sujetos que se relacionaban con Chavín de Huántar era la religión también hay evidencias concretas de representaciones de armas y de los efectos de la violencia institucionalizada en el sitio de Chavín de Huántar.

\section{Prácticas sociales implicadas}

La recuperación de contextos o restos humanos con evidencia de violencia en contextos del Centro Político Religioso nos habla de la existencia real de prácticas violentas o sacrificiales que suponen que estas se realizan periódicamente o espontáneamente pero que, en cualquier caso, estaban racionalizadas por el discurso imperante en dicho lugar. Aunque se ha planteado que no necesariamente esto se debería ver como violencia pues este concepto también es occidental, y por tanto, debería verse con "ojos andinos" es necesario señalar que independientemente de que esto sea percibido como violento, esta práctica se realiza en espacios públicos y exclusivos (indicador 6) y cuyo objetivo final es el reconocer a dichos espacios como lugares donde se sabe que allí se realizan e, incluso, suponen el consumo de partes humanas. Si esto se realiza en estos espacios y no en otros, nos habla del monopolio de los grupos de elite para controlar la vida de otros sujetos. Esto tiene como propósito final reproducir la religión en tanto coerción psíquica y fáctica y mantener el discurso siempre vivo. Asimismo, esto puede tener connotaciones con relación a las sociedades externas que reciben un mensaje de grupos que controlan la vida humana y, en algunos casos, se dan representaciones de armas no solamente sacrificiales sino que, también, pueden ser utilizadas y en- tendidas como medios ofensivos o de disuasión. Una de estas evidencias defensivas podría ser la gran muralla al norte del núcleo del sitio que delimitaría un espacio particular (Burger 1992: 164). Por último, la concentración de personas en el tiempo de mayor esplendor de Chavín de Huántar que Burger calcula entre 2000 a 3000 personas (Burger 2008: 696) también podría representar un importante contingente humano que con sus propios cuerpos podría defender al sitio de ataques. En suma, un lugar como Chavín de Huántar, en tanto propiedad particular de un grupo de personas, y que concentraba gran cantidad de productos (explotación) (indicador 2 y 9) y era una ruta importante de intercambio de bienes (indicador 1) debió poseer mecanismos físicos de defensa física más allá de la religión.

\section{Existencia de espacios de concentración de objetos muy elaborados en los edificios princi- pales}

\section{Materialidad social}

Como hemos visto, Chavín de Huántar se erige como el principal acumulador de artefactos muebles e inmuebles más importante del área. La mayoría de estos, por su propia calidad e inversión de trabajo han perdurado hasta nuestros días comenzando en la misma arquitectura y terminando en los objetos más pequeños y de materiales biológicos como el hueso. Claramente en Chavín de Huántar se acumulaban muchas más tipos de objetos de alto valor pero dadas las condiciones y el paso del tiempo estos han desaparecido como, por ejemplo, los objetos realizados en materiales botánicos.

Además, dada la investigación presente, por el momento, contextos como los de las galerías de Chavín, en especial la de las Caracolas (Rick 2008) y de las Ofrendas ${ }^{38}$ (Lumbreras 1993, 2007) (Figs. 7, 8 y 9) nos permiten acercarnos a una concentración de artefactos amortizados que comparten espacios de concentración muy

38 Se hallaron como mínimo 681 vasijas cerámicas, 46 objetos de piedra, 69 artefactos de hueso lo que hizo un número mínimo de 797 artefactos depositados allí, sin contar otros objetos como huesos humanos y animales (Lumbreras 1993: 88). 
especiales aunque no son producidos con las mismas materias primas, técnicas, estilo y proceden de diferentes áreas geográficas (Lumbreras 1993, Lumbreras et al. 2003). Sin embargo, aun así resulta interesante que todavía algunos objetos recrean diseños inspirados (imitaciones locales) en otros objetos emblemáticos de Chavín de Huántar.

\section{Prácticas sociales implicadas}

En el caso de Chavín de Huántar se aprecia que en algunos espacios específicos y muy asociados con áreas importantes o centrales de los edificios principales se hallan reunidos objetos de gran calidad y muy elaborados. Estos objetos nos indicarían una acumulación de objetos que pueden ser vistos como ofrendas de los "peregrinos" pero que también pueden ser vistos como tributos y que claramente son apropiados y extraídos de la circulación por los dirigentes mediante la religión en forma de ofrenda ${ }^{39}$. Dichos objetos a veces proceden de áreas bastante alejadas y suponen un trabajo social invertido en su producción y transporte (por ejemplo, el granito blanco o las vasijas cerámicas de Ancón) que finalmente son internados (consumidos) en el sitio. De esta forma, las vasijas cerámicas foráneas y de gran calidad, además de ser piezas importantes por sí mismas (trabajo social acumulado), también eran contenedores de alimentos de gran calidad y exóticos (banquetes).

Asimismo, esta acumulación materializada en algunos objetos solamente puede y debe ser un porcentaje bastante inferior del total del consumo de la producción social hecha por los

39 En este caso, la ofrenda sería la materialización del excedente, pues ningún individuo en situaciones naturales da algo (objetos o fuerza de trabajo) más allá de sus posibilidades y necesidades reales a pesar que esto se vea como un "sacrificio". En caso de ser así, esto supondría una alienación del individuo. Asimismo, una ofrenda no puede verse como un "sacrificio personal" pues esta ofrenda ha sido generada socialmente (incluyendo al individuo mismo) y es parte de la producción social. Para el caso que estudiamos acá, el individuo extrae de la producción social y de su consumo individual (o vida propia) para transferir como ofrenda a los teócratas quienes lo acumulan, consumen y/o distribuyen asimétricamente. dirigentes de Chavín de Huántar, pues, otra parte se habría dirigido al mantenimiento de otros grupos sociales asociados directamente a la elite. Sabemos que, además, en un ambiente donde lo más importante es generar relaciones sociales asimétricas muchos de estos objetos deben haber sido entregados a otras elites o individuos a cambio de otros bienes y servicios, cuestión que en los últimos años ha sido explorada sobre todo por la arqueología procesualista norteamericana, mediante el modelo de los "banquetes políticos" ("commensal politics") (Dietler 1996, Dietler y Hayden 2001, y ver aplicación a los Andes centrales en Dillehay 2003, Kaulicke y Dillehay 2005, Jennings y Bowser 2008) pero que ya había sido planteada originalmente por Lumbreras (1993) con relación al contexto de la Galería de las Ofrendas.

A pesar que en arqueología los contextos funerarios son los mejores indicadores de una

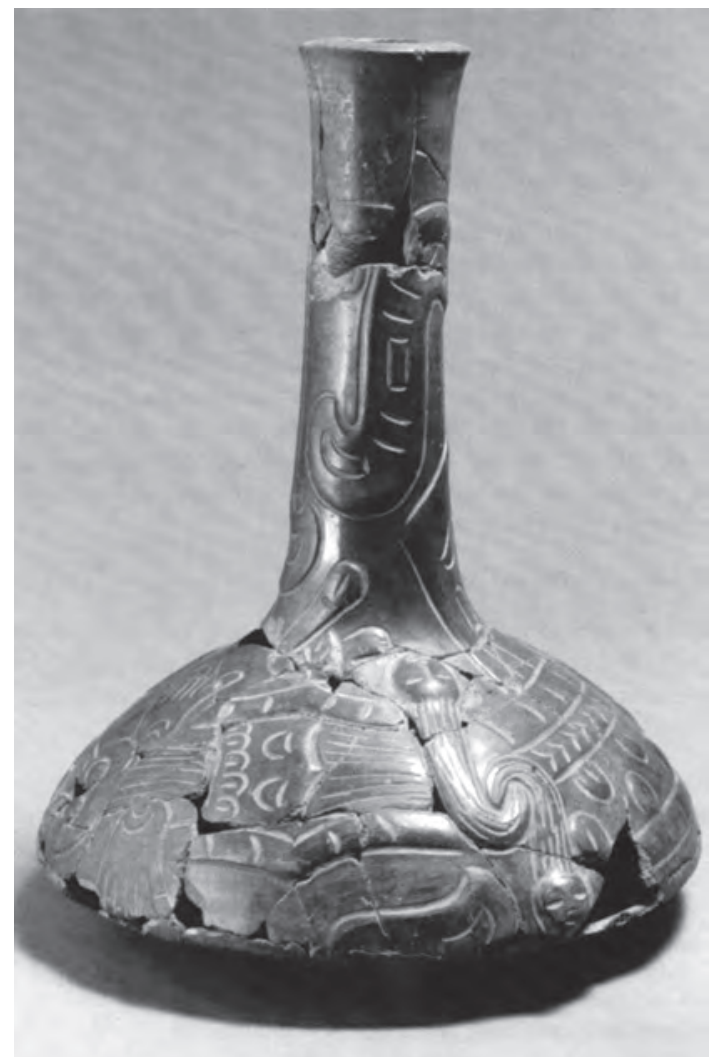

Figura 7: Botella de estilo Qotopukyo (Lumbreras 2007: fig. 245) 

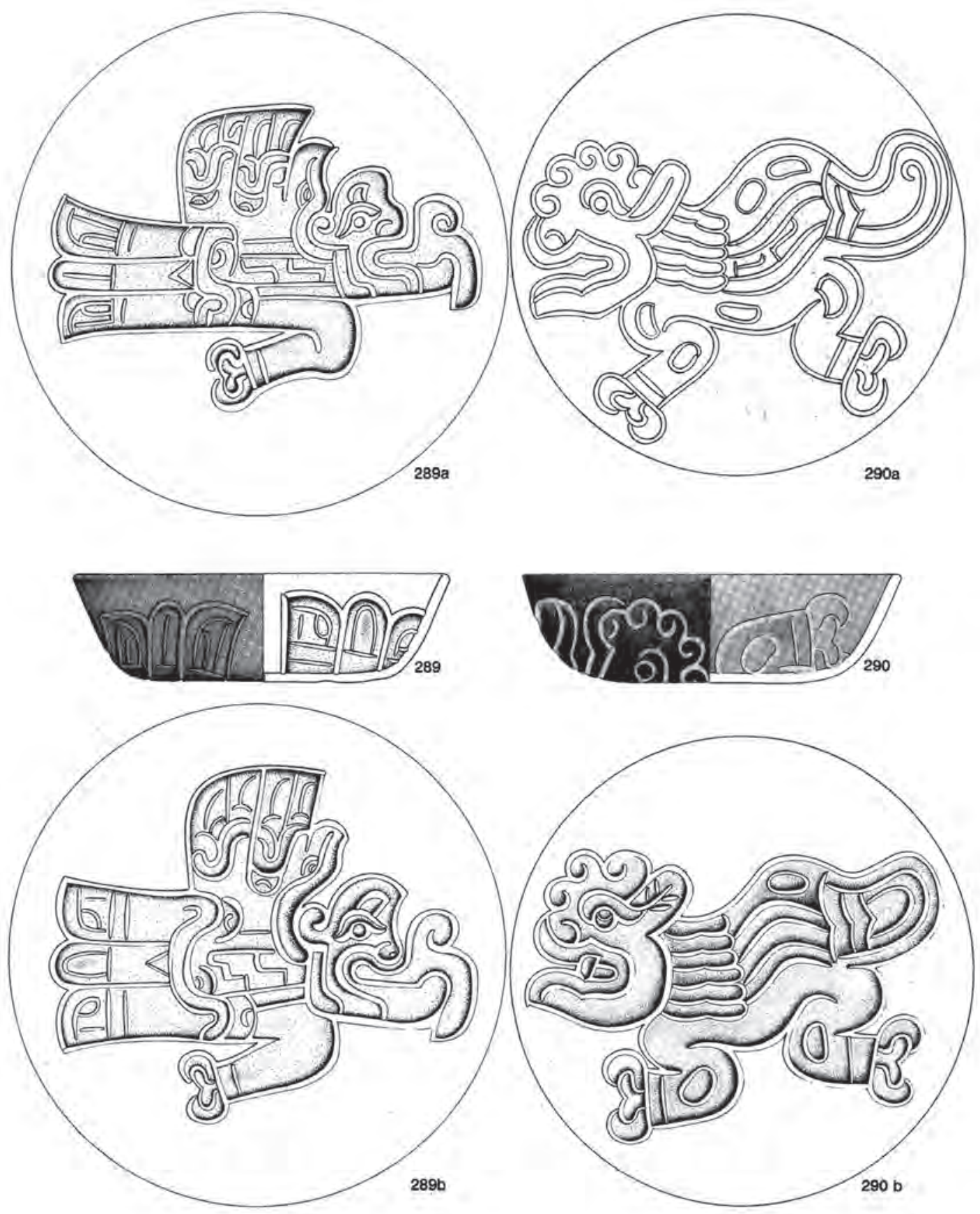

Figura 8: Vasijas cerámicas del estilo Ofrendas (Lumbreras 2007) 


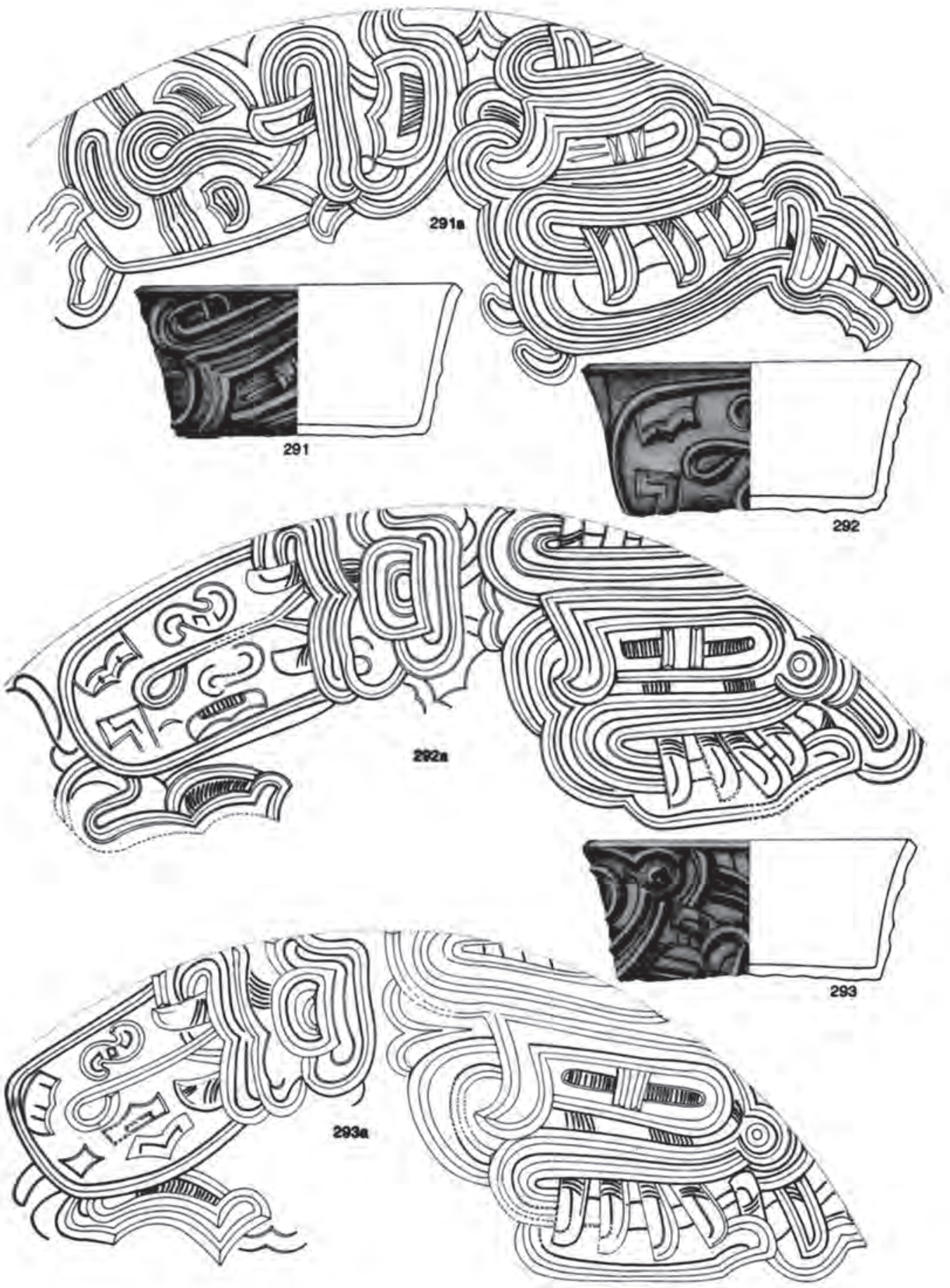

Figura 9: Vasijas cerámicas del estilo Dragoniano (según Lumbreras 2007) 
acumulación de la producción más allá de la vida de los que dirigirían una sociedad, en Chavín de Huántar esta acumulación ha permanecido elusiva, cuestión que puede deberse a la falta de investigación, conservación o, posiblemente, también debido a que por alguna práctica socioideológica esta acumulación no se haga patente en la muerte. Sin embargo, es interesante notar que en el sitio de Kunturwasi, en Cajamarca, que es temporalmente sincrónico con el apogeo del sitio de Chavín de Huántar se hallaron enterramientos con individuos acumulando grandes cantidades de artefactos, entre ellos algunos hechos de oro y con iconografía relacionada con el culto a Chavín (también ver Seki et al. 2008: 90 para Pacopampa).

Indicadores arqueológicos en las áreas asociadas directamente a los edificios principales

10. Existencia de áreas "domésticas" y/o "laborales" asociadas directamente con los edificios principales del sitio

\section{Materialidad social}

A pesar que en la superficie del sitio las estructuras no monumentales son invisibles, principalmente por los procesos de movimientos de tierras (Burger 1998: 27, Contreras 2007), excavaciones en los últimos años han comenzado a encontrar estas estructuras domésticas muy por debajo de la superficie actual en los sectores que rodean a los edificios principales (Rick 2004, Mesía 2007, Contreras 2007, Rick et al. 2009). Así pues, ya en la década de los 70s del siglo pasado una importante concentración de arquitectura de "uso habitacional" se había comenzado a reconocer alrededor de los edificios principales del sitio (Burger 1978: 304; 1998), las cuales se diferenciaban claramente de las edificaciones monumentales siendo más bien "rusticas". Estas edificaciones rectangulares y rústicas se incrementan a medida que pasa del tiempo hasta llegar a ser muy evidentes y asociadas con los edificios principales de Chavín durante la fase Janabarriu (Idem: 304) (Fig. 10). Según sus observaciones, Burger (1978: 305, 1992: 168, 1998: 289) hipotetiza que durante la fase Janabarriu el asentamiento tenía alrededor de 43 hectáreas, siendo solamente el $12 \%$ de esta extensión constituida por las construcciones monumentales, y que podría albergar de 2000 a 3000 personas (Burger 2008: 696). Lo anterior supone que Chavín de Huántar contaba con una variedad y cantidad importante de personas que estaban involucradas en las prácticas religiosas y políticas permanentemente dirigidas por la elite Chavín y produciendo alimentos y objetos para esa elite. Incluso, Burger (1992: 171, 1998: 289) llegó a diferenciar entre sectores (A y D) externos a los edificios principales que tenían producciones artesanales y consumo de alimentos y artefactos diferenciados. Los trabajos del equipo de Rick, han venido a confirmar las propuestas de Burger y complejizar nuestra perspectiva del paleopaisaje del área de Chavín de Huántar y sus diferentes sectores domésticos y artesanales más allá del área "monumental".

\section{Prácticas sociales implicadas}

Otro de los indicadores arqueológicos esenciales y universales para sostener la existencia de un estado pero, en este caso, el que se asocia con el área andina es que este debe tener una concentración de estructuras domésticas asociadas directamente con los edificios principales. Dentro de estas estructuras se puede reconocer varios niveles de ocupación humana desde los relacionados directamente con los sujetos que controlan o manejan el sitio pasando por los artesanos que producen artefactos para el grupo que maneja el sitio principal, los comuneros relacionados con el sitio hasta, finalmente, las personas que permanecen temporalmente allí. Esta jerarquía debería estar materializada en las diferencias de calidad y área de uso de los espacios domésticos y sus objetos asociados y su mayor o menor cercanía a los edificios más importantes del sitio. En este sentido, este indicador también se relacionaría con la idea de una ciudad con especialistas asociados y permanentes vinculados (atraídos) directamente con los edificios o espacios principales. Si bien, esta imagen resulta de la investigación en otras áreas del mundo, es necesaria solamente una población mínima que se relacione con el sitio para poder dirigirlo y mantenerlo y producir los objetos básicos para 
b
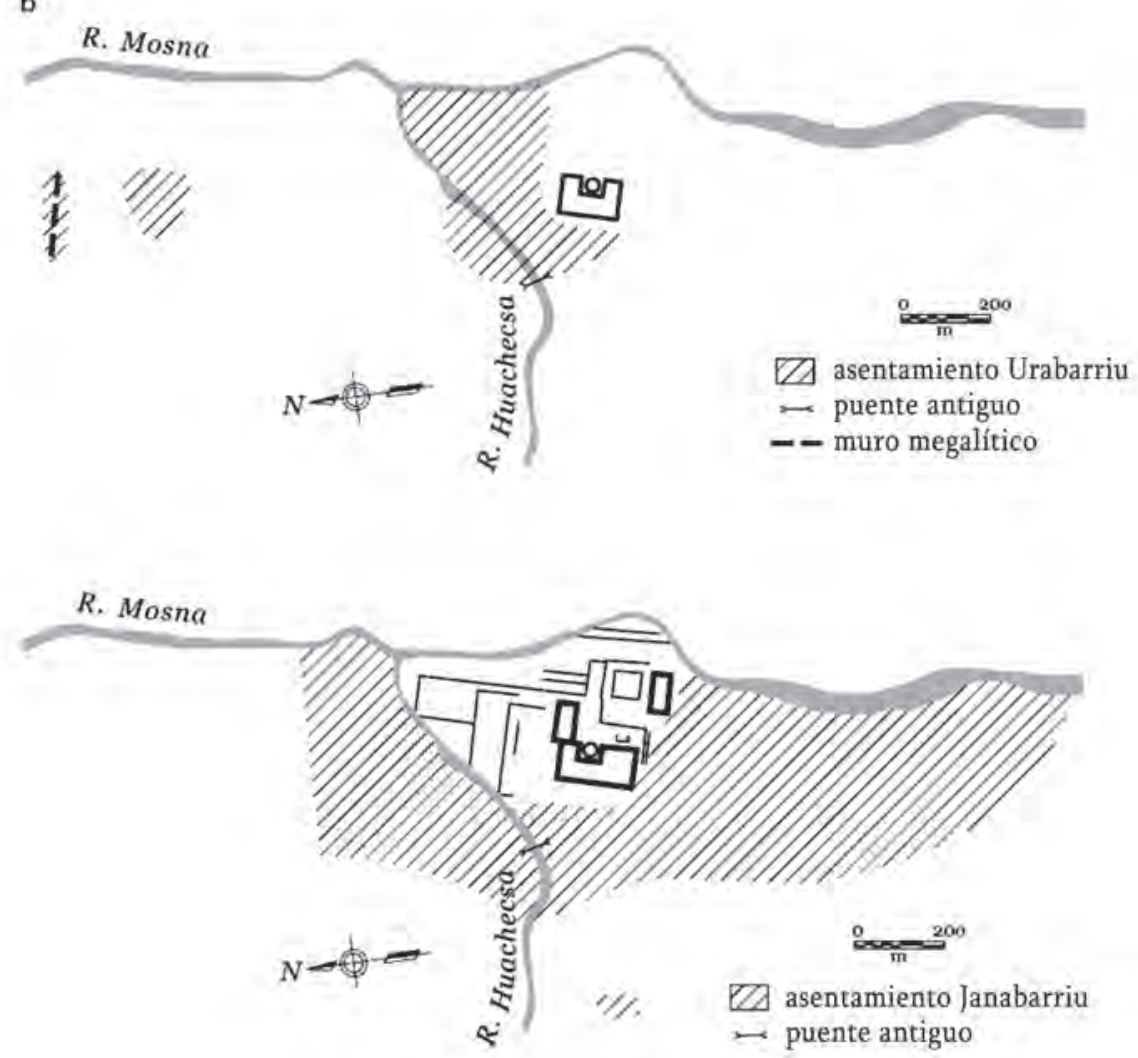

Figura 10: Crecimiento del sitio de Chavín de Huántar en las épocas Urabarriu y Janabarriu, según Makowski 2008: Fig. 32.2, basado en Burger 1992

las prácticas allí realizadas. En este sentido, y como contraparte a las ciudades del Viejo Mundo es necesario decir que muchas poblaciones relacionadas con estos sitios de carácter político religioso casi siempre viven dispersos dado que además, en el contexto andino se tiende mayormente a la ocupación del territorio andino de forma dispersa y diversa donde, por ejemplo, la agricultura extensiva demanda que los sujetos estén asociados directamente a sus campos de cultivo o los pastores a las áreas de pastizales, ubicadas generalmente en las alturas. Asimismo, es necesario decir que estas estructuras domésticas, por lo general, no son evidentes sin excavación lo que, por ejemplo, llevó a plantear a mediados del siglo pasado la existencia de "centros ceremoniales vacios", una propuesta que está siendo dejada de lado gracias a la evidencia de concentraciones de poblaciones alrededor y dentro de los espacios ceremoniales. Algo más importante es que, dado que un estado teocrático se basa en la afluencia de contingentes de personas temporalmente, es posible que estos individuos no lleguen a generar grandes volúmenes de arquitectura permanente sino más bien estructuras estacionales o temporales.

\section{Existencia de artefactos estandarizados en los edificios principales y área inmediata}

Materialidad social

Con respecto a los artefactos estandarizados justamente la producción misma de la arquitectura supone una técnica bastante similar a pesar del paso del tiempo en el sitio mismo, así como los 
bloques líticos que la decoraban con unos cánones estilísticos bastante claros y peculiares (Fig. 11). Lo mismo sucedía también con la cerámica, metalurgia, lapidaria y otras artesanías halladas en el sitio de Chavín de Huántar tanto en el núcleo monumental como en el área doméstica (Burger 1992, 1998: 32, Druc 1998). A pesar que las investigaciones recién empiezan a dar sus frutos se ha constatado la existencia de áreas de producción de artefactos asociados íntimamente al sitio (Burger 1998, Mesía 2007).

\section{Prácticas sociales implicadas}

Este es el indicador artefactual mueble más importante para definir un estado teocrático puesto que es evidente que existe una control de la producción de artefactos con funciones y características y diseños que son relevantes para un grupo social para actividades concretas y que comunican mensajes relacionados directamente con la ideología religiosa principal, espe- cialmente relacionados con la violencia simbólica allí plasmada. También, nos habla de una especialización en dicha artesanía pero, sobre todo, de su relación directa con los dirigentes de Chavín de Huántar quienes orientaron dicha producción para su uso y distribución exclusiva. En este caso, la producción está estandarizada porque, al ser medio de comunicación, este mensaje puede y debe estar enfocado en conseguir llamar la atención de sus usuarios y articularlo dentro del mensaje que quiere enviar los grupos sociales que ordenan y generan dicha producción de artefactos. Esto supondría o que los artesanos estaban controlados directamente e incluso asociados espacialmente al Centro Político Religioso o que los talleres de áreas relacionadas con este estado están reproduciendo las formas y diseños de los artefactos originales con el objetivo de realizar las mismas prácticas sociales relacionadas con estos artefactos en el centro político religioso.

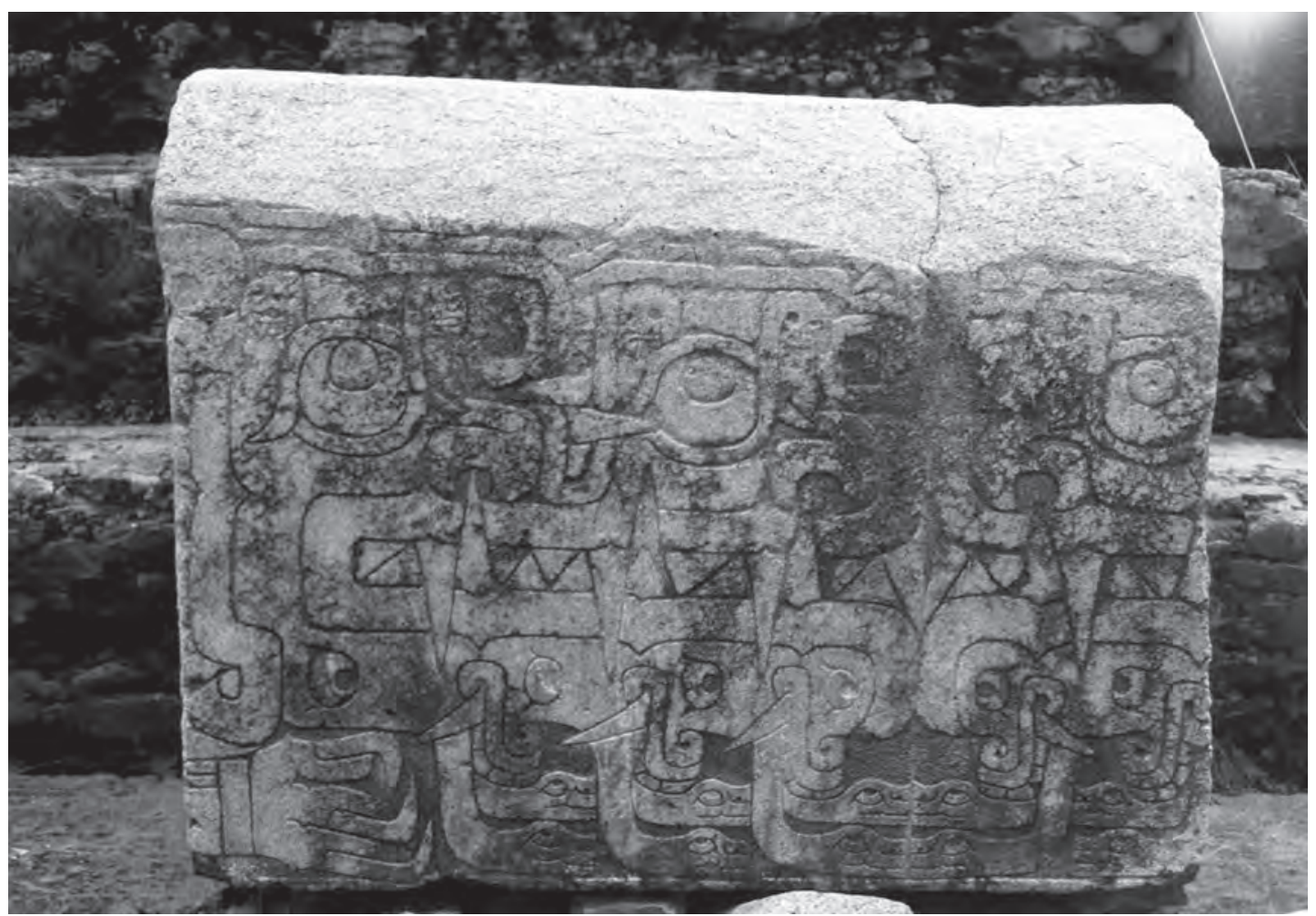

Figura 11: Bloque de granito con diseños incisos complejos en Chavín de Huántar (foto del autor) 


\section{Estructuras arquitectónicas domésticas construidas con materiales y tecnología de mayor calidad.}

\section{Materialidad social}

Recientemente, Rick (2006: 205. También ver Rick 2005: fig. 5.5) ha reportado que en el sector de La Banda, frente a Chavín de Huántar cruzando el rio Mosna existen "estructuras residenciales de aparente alto rango y habitaciones modestas probablemente contemporáneas que parecen mostrar una distinción en acceso a recursos constructivos". Adicionalmente las excavaciones de Daniel Contreras (2010) en el "Campo Oeste" comprueban observaciones previas, tan tempranas como las de Tello, de la existencia de un área con estructuras arquitectónicas relacionadas con el núcleo monumental. En el caso de las excavaciones de Contreras, incluso, se ha llegado a definir un edificio de la Tradición Mito contemporáneo con los edificios monumentales, alrededor del 800 a.C. ("Fase Negro y Blanco" según Rodríguez Kembel 2008) lo que supone que, alrededor del núcleo arquitectónico, existieron otros sectores edificados que incluían espacios rituales y otros por descubrir de muy buena factura y diseño más allá del doméstico-comunitario.

\section{Prácticas sociales implicadas}

A lo largo del tiempo, en la arqueología andina hemos pasado de una concepción de sitios como el de Chavín de Huántar como "Centros ceremoniales vacios" (Bennett 1946: 82, Bennett y Bird 1949:133) hasta "Ciudades" (Rowe 1963). Si bien, el debate acerca de las ciudades en los Andes prehispánicos todavía sigue abierto (Shady 2009, Makowski 2008) es importante entender que las ciudades son las concreciones históricas de una serie de formas de producción y relaciones sociales específicas. Si bien, el tipo de ciudad andina es posiblemente diferente a la de otros ejemplos del mundo, su comparación no debería llevar a su infravaloración por no contener los elementos civilizatorios de estas otras áreas del mundo. Afortunadamente, la investigación arqueológica actual nos está ayudando a comprender como es que se dieron las concentraciones humanas tempranas en los Andes y vemos que a partir de las investigaciones de Chavín de Huántar contamos con estructuras arquitectónicas que bien pueden ser evidencia de espacios domésticos de elite o de mayor rango. Si bien, por el momento no se ha definido exactamente la(s) residencia(s) de la elite principal de Chavín de Huántar (que bien puede haber estado albergada en las partes superiores o contiguas a las pirámides truncas) queda claro que afuera mismo de los edificios existían residencias de personas que no eran simples comuneros y estaban totalmente relacionados con la administración y control de estos edificios principales.

\section{Acumulación de artefactos estandarizados producidos localmente o no, solo en algunos contextos domésticos afuera de los edificios principales del sitio}

\section{Materialidad social}

A pesar que, como hemos visto, algunos estudios (Lumbreras et al. 2003) han planteado que muchas piezas cerámicas de gran calidad artística no fueron producidas localmente (lo que contradeciría la existencia de especialistas en el mismo sitio, un requisito de ciudad y en la tesis childiana de un estado), sin embargo, también se ha podido reconocer una producción cerámica local que se interna en los edificios principales de Chavín de Huántar (Wagner et al. 1986) pero que también se consume en los alrededores inmediatos de dichos edificios (Druc 1998).

Así pues, independientemente de la procedencia de los artefactos, contextos arqueológicos como los rescatados por Burger o Lumbreras (1993) nos hablan de una concentración de artefactos que tienen una alta calidad o inversión de fuerza de trabajo. Como el trabajo de Burger y los de Rick han demostrado, el sitio de Chavín de Huántar está rodeado por toda un área de actividades sociales donde también se encuentra cerámica de alta calidad y procedente de otras áreas. Si bien, todavía no se han hallado tumbas que acumulen objetos de gran calidad, la verdad es que tampoco se han encontrado los de otros tipos. Aun así, si en la muerte no se encuentra materializada dicha acumulación (lo que podría justificarse por algún otro tipo de práctica fune- 
raria que habría de explorar), el indicador anterior señala que las estructuras de mejor calidad contenían estos artefactos y que las diferencian de otras estructuras del mismo sitio y, más importante, de otros sitios de la misma región.

\section{Prácticas sociales implicadas}

La existencia o no de artefactos en contextos sincrónicos nos remite al hecho de que diferentes grupos sociales tienen acceso diferenciado a la producción social. Este hecho hace evidente que existen sujetos que acumulan el trabajo de otros y otros sujetos están excluidos o marginados en la circulación de los objetos. Dicha relación desigual que se puede ver en espacios domésticos también puede verse en los contextos funerarios los cuales han sido los más trabajados en los Andes. No obstante, en el caso de los estados teocráticos andinos, como en el caso de Chavín de Huántar, los cementerios excavados son mínimos y, de hecho, son pocas las tumbas de elite conocidas para este tipo de sociedad (indicador 9). De esta manera, es posible que su inexistencia se deba a prácticas sociales que invisibilizan en la muerte esa acumulación de la producción social en tumbas que si se verá más adelante en otras sociedades andinas.

Los primeros estados teocráticos andinos generalmente se erigen sobre las sociedades comunitarias donde la propiedad es colectiva. Sin embargo, durante el estado, la propiedad de los teócratas se torna particular y no todavía privada o individual por lo que la mayor acumulación no se orientaría hacia individuos concretos en la muerte, lo que además también generaría demasiadas contradicciones al no poder legitimarlas y al ser tan evidentes para las personas sujetas y/o ofrendatarias. Esto explicaría, por ejemplo, la inexistencia de cementerios de elite o que los enterramientos no acumulan más allá de unos cuantos objetos de alto valor. Además, parece que la acumulación de artefactos en la tumbas (incluyendo los metales que siguen teniendo una importancia pragmática-simbólica) no se da hasta el periodo Intermedio Temprano como la que se dio en la sociedad Moche.
Indicadores arqueológicos en las áreas alejadas del centro político religioso y zona residencial de Chavin de Huántar

\section{Existencia de asentamientos monumentales que repiten el diseño y técnica y relacionados con materiales originales del sitio estudiado}

Materialidad social

Variados estudios desde la época de Tello han reconocido una filiación entre diferentes sitios del área andina central con el sitio de Chavín de Huantar. A pesar que esos planteamientos surgían de una perspectiva culturalista-difusionista (por ejemplo ver Carrión Cachot 1948) en el presente se reconoce que diferentes sitios, sobre todo, en los valles de Jequetepeque (Inokuchi 2008), Chotano (Morales 2008), Casma (Bischof 2008), Nepeña (Shibata 2008) y Rímac (Ravines 1984) reprodujeron elementos arquitectónicos del sitio de Chavin. Sin embargo, por los fechados radiocarbónicos, más parece ser que las elites locales ya constituidas son las que reciben o se apropian de esos elementos para reproducir su poder económico y político. También, es probable que muchos elementos hayan sido tomados por la elite de Chavín de Huántar para reproducir su propio poder económico y político. Sin embargo, todavía existen sitios que definitivamente si tuvieron una fundación propiciada por la elite albergada en el sitio de Chavín de Huántar, por lo menos, dentro de la misma área del Mosna (por ejemplo, Pojoc y Wamanwain).

\section{Prácticas sociales implicadas}

Aunque este no es requisito para la existencia de un estado teocrático andino puesto que el estado se puede restringir al mismo sitio (ciudadestado) y áreas muy cercanas, en algunos casos es necesario deslindar sí las reiteraciones de diseños y arquitectura de sitios cercanos, aunque en la órbita del sitio principal, corresponden a centros secundarios dentro de un territorio controlado por dicho estado teocrático andino. Para ello, además de la arquitectura, se deberán encontrar otros elementos como artefactos e, incluso, restos de los individuos procedentes del 
sitio nuclear. Esto nos hablaría de la territorialidad del estado y de su expansión mediante la creación de dependencias de su culto en áreas que le son interesantes para seguir reproduciendo económica y políticamente su estado teocrático. De todas formas, es posible que la inexistencia de una gran fuerza militar haya hecho difícil una expansión territorial por la fuerza en otros territorios.

Un problema por resolver sería reconocer que tan sincrónicos eran estos asentamientos pues las comparaciones estilísticas cerámicas e, incluso, los fechados radiocarbónicos todavía ofrecen rangos de tiempo muy amplios y podríamos estar contemporaneizando asentamientos que pueden representar una sucesión de eventos.

\section{Existencia de artefactos de la misma mor-} fología e iconografía fuera del sitio estudiado, especialmente en otros contextos de "elite"

\section{Materialidad social}

Más allá del sitio mismo, se han reconocido algunos sitios que podrían haber estado ligados (políticamente) directamente a Chavín de Huántar conteniendo objetos del mismo sitio o producidos con las mismas características formales (Tello 1960, Watanabe 2008, Burger y Matos 2002, Burger y Salazar 2010). Asimismo, objetos producidos en otras áreas llegaron a Chavín de Huántar desde distancias cortas y lejanas lo que refiere la existencia de una relación entre elites de otras áreas y de la influencia en ellas por parte de este sitio tan importante (Lumbreras 1993: 197, Rick 2006, Rick et al. 2009: 105). Sin embargo, es posible pensar que el sitio de Chavín de Huántar ocupaba un territorio bastante constreñido al sector superior del valle de Mosna. Las posibles colonias de las que hablaba Carrión Cachot (1948), por ejemplo, serian más bien un anacronismo de las perspectivas difusionistas e histórico culturales en la arqueología peruana las cuales ecualizaban cerámica o textiles con existencia de colonos. Sin embargo, independientemente de como hayan llegado a estas zonas tan alejadas es evidente que artefactos inspirados en los objetos de Chavín de Huántar (o imitaciones) llegaron a áreas bastante alejadas reproduciendo a menor escala las prac- ticas político- religiosas del sitio del Callejón de Conchucos (por ejemplo, textiles (Stone 1983, Kaulicke et al. 2009))

\section{Prácticas sociales implicadas}

La aparición de los objetos antes mencionados en contextos alejados del sitio principal y claramente dentro de otro tipo de sociedad nos remite al hecho de la existencia de relaciones con otros grupos sociales, especialmente con otras elites. Estas son relaciones con otras elites dependientes o co-dependientes pero que también nos hablan de relaciones con otros grupos sociales que mediatizan la explotación fuera del sitio o concentración de artefactos y productos de otras áreas (asistentes o "peregrinos" de diferentes niveles sociales). Esto también supone que a cambio de dichos objetos se podría haber dado la obtención de otros recursos y/o objetos exóticos mediante la ofrenda o intercambio.

\section{Existencia de asentamientos domésticos ale- jados pero relacionados directamente con el sitio estudiado}

\section{Materialidad social}

Julio C. Tello (1960: 147-157, con aportes de Julio Espejo Nuñez), Burger (1983, 1992: 130), Wilhelm Diessl (2004), Bebel Ibarra (2009), entre otros, han señalado mediante sus reconocimientos e investigaciones en la cuenca del valle del Mosna o Pukcha una serie de asentamientos relacionados con el sitio de Chavín de Huántar, especialmente los encontrados por Tello y Espejo Nuñez con muestras de litoescultura que recrean el estilo del sitio principal. Aunque esta relación todavía es muy poco clara, artefactos y estilos arquitectónicos que reproducen los del sitio de Chavín de Huántar se evidencian en dichos sitios planteando una filiación contemporánea y directa que necesita ser profundizada.

\section{Prácticas sociales implicadas}

Asociado con el anterior indicador, la existencia de asentamientos domésticos alejados del 
sitio principal reflejaría la existencia de comunidades sujetas o vinculadas directamente con Chavín de Huántar. Esta dependencia directa o indirecta es posible dado que un estado como Chavín necesita de dicha fuerza de trabajo para generar más recursos de forma directa e incluso necesita de productos que no pueden ser producidos en el área inmediatamente cercana al sitio ya sean productos alimenticios o materias primas para elaborar otros artefactos o productos.

En el caso de estos sitios, es posible detectarlos cuando encontremos objetos o individuos procedentes del mismo Chavín o personas con objetos producidos allí. Sin embargo, como vimos arriba es posible que sociedades que tuvieron relación directa con Chavín de Huántar hayan estado consumiendo productos no manufacturados en ese mismo sitio puesto que la elite está distribuyendo objetos de otras áreas.

Del mismo modo que con el indicador anterior, deberemos encontrar una relación basada en individuos o artefactos procedentes del sitio original. Sin embargo, en este caso se trataría de reconocer en los espacios domésticos tal incursión. Aunque este indicador es menos evidente, puesto que a este nivel quizá solamente las elites locales son las accesitarias a los objetos del lugar nuclear, sí se define una relación directa entre asentamientos domésticos alejados y asentamiento nuclear estaríamos hablando que la explotación de la fuerza de trabajo y producción de objetos vas más allá del área nuclear del estado teocrático andino. Eso nos podría acercar a la densidad poblacional en los tiempos del apogeo de Chavín de Huántar pero, más importante, de la relación y la fuerza de trabajo disponible y/o empleada por las elites. Es sabido, además, por las fuentes etnohistóricas tardías que una forma de explotación directa de tierra agrícolas o recursos naturales se da a través de la existencia de propiedades de las deidades como es el caso de la "tierras del sol" del Imperio Inca. De este modo, en estos espacios se podría estar generando la producción básica de alimentos necesaria para reproducir a la elite teocrática principalmente, aparte de las ofrendas.

\section{COMENTARIOS FINALES}

La génesis del estado teocrático andino de Chavín de Huántar se encuentra en la confluencia de una serie de factores económicos y políticos que le dan soporte y que re-apropiados y reproducidos por las elites lo mantienen a través de un largo tiempo de manera exitosa. Uno de esos factores de mantenimiento y que es retomado de prácticas sociodeológicas previas (como el shamanismo) pero que, en ese momento respaldan otro estado de cosas, es la religión, la cual se torna en una institución política que ordena y mantiene la estabilidad social dentro de la contradicción social surgida en el desarrollo de la explotación de un grupo social dominante hacia una gran cantidad de individuos instalados y atraídos al Centro Político Religioso pero que, a medida que fue aumentando demográficamente y estamentalmente, necesitó de la atracción de otros grupos de personas para mantener y reproducir material e ideológicamente a la elite. Este estado de cosas se mantuvo por lo menos unos 700 años creciendo y asimilando otras prácticas sociales pero reconduciéndose hacia objetivos concretos de la elite. Claro que este estado de cosas también supuso un mejoramiento de la vida de algunos individuos que se asociaron con la elite dominante e incluso grupos de artesanos y especialistas y generó un espacio de encuentro social para el intercambio de artefactos e información y otros beneficios. Sin embargo, en esta situación estos grupos no fueron beneficiados objetivamente de la misma forma sino que más bien fueron dependientes de la existencia de dicha elite.

Aproximadamente alrededor de los 400 a.C., el desarrollo del sitio de Chavín de Huántar se detuvo y a continuación los edificios principales son utilizados para prácticas sociales domésticas alejadas de su función para los que fueron construidos. Además, la producción material de la sociedad allí reunida se detiene y en otras áreas relacionadas directamente también. Todo esto señala el momento en el cual las elites de Chavín de Huántar ya no pudieron seguir sosteniendo y manteniendo la situación y el control del orden social que siempre estuvo en tensión y se desintegra como formación sociopolítica y 
socioeconómica. Esta crisis del sistema generará muy diversas reacciones en diferentes lugares del mundo andino, sobre todo los relacionados directamente con Chavín de Huántar. En dicho contexto no sorprende que en diferentes espacios de los Andes se abriese una época en la cual se hicieron evidentes los conflictos intra e intersociales y se pase a una época en que las producciones de arquitectura y objetos se tornen más regionalistas o localistas. El abandono de la producción de arquitectura y artefactos inspirados en los temas de Chavín de Huántar y otros relacionados hacen patente el abandono y el rechazo de las prácticas religiosas de estos sitios. Su reapropiación por otras sociedades estatales más adelante, retomará ese trabajo social acumulado en Chavín de Huántar que fue exitoso durante varias centurias.

En este artículo hemos planteado la existencia, contenido y dinámica de una forma política que hemos denominado Estado Teocrático Andino. Esta forma sociopolítica se explica desde su propia materialidad social en los Andes prehispánicos precapitalistas y que tiene su fundamento en las evidencias arqueológicas acumuladas en el sitio Chavín de Huántar. La nuestra, como toda propuesta arqueológica, se origina desde una perspectiva teórica que, en nuestro caso, es el materialismo histórico. Como todas las perspectivas teóricas actuales esta se basa en desarrollos de la ciencia occidental. Sin embargo, una vez que nos enfrentamos directamente con los objetos arqueológicos de Chavín de Huántar y tomando en cuenta que la explicación del pasado siempre se produce en el presente y, por consecuencia, está condicionada por nuestras formas de ver el mundo, creemos que el materialismo histórico, según lo entendían los clásicos marxistas es, dentro de las propuestas al uso, capaz de dar cuenta de una formación social original en los Andes prehispánicos al considerar que los objetos arqueológicos y su producción social son históricamente contingentes. Asimismo, como todas las demás, nuestra propuesta también necesitará ser contrastada en profundidad pero supone, también, como todo planteamiento, una propuesta que está en construcción.
Por otra parte, creemos que Chavín de Huántar no fue el único caso de Estado Teocrático Andino temprano. Otros casos que no hemos podido tratar aquí estarían encarnados en los sitios de Moxeke-Sechín Alto (Pozorski y Pozorski 2008) en el valle de Casma, Caballo Muerto (1500 a.C-400 a.C.) en el valle medio de Moche y asociados (Pozorski 1983, Alva 2008, Masato y Martínez 2008), Kunturwasi (950 a.C.- 50 a.C.) en el valle alto del Jequetepeque (Inokuchi 2008), Pacopampa (1200 a.C-200 a.C.) en el valle del Chotano (Seki et al. 2008, Morales 2008), algunos de los "Templos en U" de la costa central como Garagay en el valle del Rímac (1600 a.C.600 a.C.40) (Ravines e Isbell 1975, Burger y Salazar 2010: 24, Rick et al. 2008), los sitios asociados con la tradición Paracas en Chincha (800 a.C.100 a.C.) (Canziani 1992, Canziani 2009: $155-$ 167) y Pukara (500 a.C.-350 a.C.) en la cuenca norte del Titicaca (Stanish 2003, Tantaleán 2010). Obviamente, cada uno de estos casos de estudio tiene algunas particularidades producto de su trayectoria histórica pero comparten la mayoría de los indicadores planteados para Chavín de Huántar. En todo caso, es necesario investigar específicamente cada uno de estos fenómenos sociales.

Interesantemente todos esos otros candidatos de estados teocráticos andinos estaban relacionados con un tiempo en el que la agricultura, mediante técnicas hidráulicas muy desarrolladas, ya estaba en pleno funcionamiento y expansión. Esto concuerda con los tempranos planteamientos de Lumbreras acerca de que la agricultura era la actividad principal que podía generar toda una serie de relaciones sociales y de propiedad y excedentes como también se veía en el Neolítico del Viejo Mundo. Todos los casos mencionados, tuvieron un rol importante en la formación del estado temprano en los Andes pero, sobre todo, dentro de su historia local al generar, por primera vez, la institucionalización de la desigualdad social y el control de las fuerzas productivas históricamente allí constituidas a través de una

\footnotetext{
40 Estas son fechas aproximadas que están basadas en los rangos temporales otorgados por los investigadores pues existen algunos problemas con los fechados radiocarbónicos proporcionados por Ravines e Isbell (Moore 1996: 35, Burger y Salazar 2010: 24).
} 
religión utilizada como medio de coerción física y psicológica. Estas fuerzas productivas habían alcanzado un nivel suficiente, gracias especialmente la agricultura, la misma que también podía ser apropiada mediante la religión pero sobre todo al instalar los centros políticos religiosos en los mismos valles y así controlar su distribución. Por ello, es significativo que todos estos centros políticos religiosos generaron o se afiliaron a un culto religioso local o extralocal, incluyendo el de Chavín de Huántar. Esto es importante pues independientemente de que sean "estados primarios" o "secundarios", deben ser asumidos como la práctica de una elite local que reprodujo la asimetría social y se empoderó políticamente mediante estrategias diversas entre las cuales la religión fue el elemento más importante para generar el sitio principal y mantener a sus gestores y usuarios principales.

A diferencia de los ejemplos citados, la forma de producción principal en el periodo Arcaico Superior (3000 a.C.-1800 a.C.) y en especial en el valle de Supe y su litoral, por lo que sabemos, fue la pesca pues la agricultura todavía no estaba tan desarrollada, sobre todo en el interior de los valles (Shady 2008, Haas y Creamer 2006: 752). De allí que su fenomenología (forma de producción dominante, tipo de propiedad, etc.) sea diferente lo mismo que su concreción arqueológica. Un hecho que hay que destacar es que en regímenes agrícolas las poblaciones se hallan en los fondos de valle sujetas a sus tierras y produciendo con relación a las fuentes de agua y períodos agrícolas. Esto quizá ayude a entender que, sí Caral fue un primer estado en esa región (aunque ver Haas y Creamer 2006), este estaría basado en el consumo de la producción marina y la concentración del intercambio interregional, con la producción agrícola en un porcentaje menor, especializada tal vez en el cultivo de plantas como el algodón utilizado como medio de producción, para hacer redes de pesca. Asimismo, más allá de alguna evidencia de algunos de los indicadores aquí propuestos para Chavín de Huántar: ubicación privilegiada, principal concentración de arquitectura, estructuras asociadas a fenómenos celestes, espacios inclusivos y exclusivos, áreas domesticas asociadas a los edificios principales, etc. uno de los elementos para hablar efectivamente de un grupo teocrático que utilizó la religión como justificación y medio de control y coerción social no está materializado en su registro arqueológico. Si esta existió o no, todavía es poco evidente en los estudios actuales y deberá ser planteado quizá desde la óptica de una sociedad que fundamentó su existencia objetiva en el consumo de la actividad pesquera y marisquera y la agricultura muy especializada y con una religión animista y/o iconoclasta que no representaba mediante imágenes a las fuerzas naturales y sobrenaturales que movían y/o controlaban el mundo. Por el momento, planteamos que, sí Caral fue un estado, este sería un Estado Pragmático, donde el control principal de la elite estaba en la medición del tiempo, ciclos agrícolas y marítimos mediante indicadores climáticos y la observación de los astros y el control del movimiento social intravalle. Además, este tipo de estado también podría tener una religión naturalista o animista, como en otros ejemplos universales, la cual no requiere y/o niega la posibilidad de representar a entidades sobrenaturales, un tipo de iconoclasia andina. Las únicas representaciones recurrentes que tenemos serían las figurinas antropomorfas de barro crudo, una tradición que se rastrea desde la costa ecuatoriana en esos tiempos para sociedades de diferentes estructuras sociopolíticas y no exclusivamente estados. Sin embargo, incluso en esas figurinas tampoco se reconoce ninguna estandarización y más bien parecen cuestiones votivas. En realidad, lo que falta por hacer en el caso de Caral es tratar de generar una metodología apropiada para reconocer las características formales de la sociedad, evitar los juicios a priori y darle una entidad propia basada en su propia naturaleza.

Para terminar, esperamos que esta propuesta y, sobre todo, los indicadores arqueológicos que hemos presentado sirvan para generar una discusión académica más amplia y que esté más fundamentada en los objetos arqueológicos y dejemos de depender cada vez menos de los modelos arqueológicos y antropológicos generados en otras áreas del mundo y a dejarnos de comparar con ellos para poder explicarnos, regresemos la vista a la realidad prehispánica andina y en un futuro cercano desarrollemos una teoría arqueo- 
lógica andina que tenga el mismo potencial explicativo para dar cuenta de fenómenos sociales propios aunque, como hemos visto, también con su cuota de universalidad.

\section{Agradecimientos}

Uno de los propósitos de escribir este texto fue tratar de saldar una deuda con la arqueología de Ancash adquirida a finales de los años 90s cuando trabajé una temporada allí. En esa ocasión tuve la oportunidad de conocer Chavín de Huántar. Muchas cosas han pasado hasta ahora para poder retomar el reto de tratar de explicar este maravilloso sitio arqueológico. Pese a ello, todavía me sigue llamando la atención este sitio por sus innumerables usos pasados y presentes. Este texto ha sido posible también gracias a un sinnúmero de personas que me han ayudado a generar una visión, todavía esquemática del sitio y los fenómenos sociales relacionados. En primer lugar, quiero agradecer al Dr. Luis Guillermo Lumbreras por haberme cedido mucho de su tiempo para conversar sobre Chavín de Huántar y el estado prehispánico andino, leer un borrador de este texto y alentarme a publicarlo. También, quiero agradecer a Kzrysztof Makowski por sostener conversaciones conmigo sobre estos temas. Quiero agradecer especialmente a Segundo Vásquez por su generosidad y amistad para con este limeño que llegó al norte para re-encontrarse con un lugar que siempre le había generado curiosidad. Finalmente a los compañeros Alex Gonzales Panta, Carlos Zapata Benítes y Lorenzo Risco con quienes discutí inicialmente muchos de estos planteamientos y en especial a Kelita Pérez Cubas con quien encontré la paz necesaria para reflexionar sobre el Estado Teocrático Andino. Sin embargo, como es de justicia, eximo a todos ellos de mis errores y falencias en este texto.

\section{BibliografíA}

Adams, Robert

2001 "Complexity in Archaic States". Journal of Anthropological Archaeology, 20: 345 360.
Alva, Ignacio

2008 "Los complejos del cerro Ventarrón y Collud-Zarpán: del Precerámico al Formativo en el valle de Lambayeque". Boletín de Arqueología PUCP, 12: 97-117.

Bate, Luis Felipe

1984 "Hipótesis sobre la sociedad clasista Inicial". Boletín de Antropología Americana, 9: 47-86.

Baraybar, José Pablo

1993 "Identificación de los huesos humanos". Apéndice II. En Lumbreras, Luis. Chavín de Huántar. Excavaciones en la Galería de las Ofrendas: 394-402. KAVA. Mainz am Rhein.

Bennett, Wendell

1944 The North Highlands of Peru. Excavations in the Callejon de Huaylas and Chavin de Huántar, Anthropological Papers of the American Museum of Natural History, 39, parte 1. New York.

1946 "The Archaeology of Central Andes". En Steward, Julian (ed.): Handbook of South American Indians, Vol. 2: 61-147. Bureau of American Ethnology. Smithsonian. Washington D.C.

Bennett, Wendell y Junius Bird

1949 Andean Culture History. American Museum of Natural History. New York.

Billman, Brian

2002 "Irrigation and the origins of the southern Moche State on the North Coast of Peru". Latin American Antiquity, 13: 371 400.

Bischof, Henning

1985 "Los orígenes del estilo Chavín". Resumen en castellano del artículo "Zur Entstehung des Chavin-Stils in Alt-Peru" publicado en Beiträge zur Allgemeinen und Vergleichenden Archäologie, 6 (1984): 355-452.

1997 "Cerro Blanco, Valle de Nepeña, Perúun sitio del Horizonte Temprano en emergencia". En Bonnier, E. y H. Bischof (eds.): Archaeologica Peruana 2: 202-234. Sociedad Arqueológica Peruano-Alemana/Reiss-Museum. Mannheim. 
2008 "Context and contents of Early Chavin Art". En Conklin, William y Jeffrey Quilter (eds.): Chavin: Art, architecture, and culture: 107-141. Cotsen Institute of Archaeology, UCLA. Los Angeles.

Blanton, Richard; Gary Feinman; Stephen Kowalewski; Peter Peregrine

1996 "A dual-Processual theory for the evolution of Mesoamerican Civilization". Current Anthropology, 37(1):1-14.

Burger, Richard

1978 "Los asentamientos poblacionales iniciales de Chavín de Huántar, Perú: un informe preliminar". En Matos, Ramiro (ed.): III Congreso Peruano del Hombre y la Cultura Andina. Actas y Trabajos. Tomo I: 294-309. Lima.

1983 "Pojoc y Waman Wain: Two Early Horizon villages in the Chavín heartland". Nawpa Pacha, 20: 3-40.

1992 Chavin and the origins of Andean Civilization. Thames \& Hudson. Londres.

1998 Excavaciones en Chavín de Huántar. PUCP. Lima.

2008 "Chavín de Huántar and its sphere of influence". Silverman, Helaine y William H. Isbell (eds.): Handbook of South American Archaeology: 681-703. Springer. New York.

Burger, Richard; Lucy Salazar

2010 La Cultura Manchay y la Inspiración Costeña para la Civilización Altoandina de Chavín. En Romero, Rubén y Trine Svendsen (eds.): Arqueología en el Perú. Nuevos Aportes para el Estudio de las Sociedades Andinas Prehispánicas: 13-37. UNFV. Lima.

Burger, Richard y Ramiro Matos

2002 Atalla: A Center on the Periphery of thee Chavin Horizon. Latin American Antiquity, 13(2): 153-177

Burger, Richard, Frank Asaro y Helen Michel

1998 "Los artefactos de obsidiana en Chavín de Huántar y sus fuentes geológicas”. En Burger, Richard: Excavaciones en Chavín de Huántar: 244-251. PUCP. Lima.
Campana, Cristóbal

1995 Arte Chavín. Análisis estructural de formas e imágenes. Universidad Nacional Federico Villarreal. Lima.

Canziani, José

1992 "Arquitectura y urbanismo del periodo Paracas en el valle de Chincha". Gaceta Arqueológica Andina, 22: 87-117.

2009 Ciudad y territorio en los Andes. Contribuciones a la historia del urbanismo prehispánico. PUCP. Lima.

Carneiro, Robert

1970 "A theory of the origins of state". Science, 169: 733-738

Carrión Cachot, Rebeca

1948 "La cultura Chavín: dos nuevas colonias. Kuntur Wasi y Ancón”. Revista del Museo Nacional de Antropología y Arqueología, 2(1): 99-172.

Chapman, Robert

2008 "Alternative states". En Habu, J.; C. Fawcett y J. M. Matsunaga (eds.): Evaluating Multiple Narratives: Beyond Nationalist, Colonialist, Imperialist Archaeologies: 144-165. Springer. New York.

Childe, Gordon

1947 History. Cobbett Press. Londres.

1950 "The urban revolution". Town Planning Review, 21(1): 3-17.

Cisneros, Leonor y Luis Lumbreras

1980 Historia general del Ejército peruano. Los orígenes. Comisión Permanente de la Historia del Ejercito del Perú. Lima.

Contreras, Daniel

2007 Sociopolitical and geomorphologic dynamics at Chavín, Peru. Tesis doctoral. Department of Anthropological Sciences. Stanford University. Palo Alto

2010 "A Mito-Style structure at Chavin de Huántar: dating and implications". Latin American Antiquity, 21(1): 3-21.

Conklin, William y Jeffrey Quilter

2008 "Introduction". En Conklin, William y Jeffrey Quilter (eds.): Chavin: art, architecture, and culture: xxvii-xxxi. Cotsen Institute of Archaeology, UCLA. Los Angeles. 
Curatola, Marco

1991 "Iconografía Chavín: El dios de los grandes colmillos". En Los Incas y el Antiguo Perú. 3000 años de historia: 196-217. Sociedad Estatal Quinto Centenario. Madrid.

Dacal, Ramón; David Watters

2005 "Three stages in the history of cuban archaeology". En Curet, L., Antonio Shannon, Lee Dawdy; Gabino La Rosa Corzo (eds.): Dialogues in cuban archaeology: 29-40. The University of Alabama Press. Tuscaloosa.

Dietler, Michael

1996 "Feast and commensal politics in the political economy: food, power, and status in orehistoric Europe". En Weissner, P. y W. Schienfenhovel (eds.): Food and the status quest: an interdisciplinary perspective: 87-125. Berghahn Books. Oxford.

Dietler, Michael y Brian Hayden

2001 Feasts. archaeological and ethnographic perspectives on food, politics, and power. Smithsonian Institution Press. Washington y Londres.

Diessl, Wilhelm

2004 Huántar, San Marcos, Chavín. Sitios arqueológicos en la sierra de Ancash. Instituto Cultural Rvna. Lima.

Eller, Jack

2007 Introducing anthropology of religion. Culture to the ultimate. Routledge. New York.

Dillehay, Tom

2003 "El colonialismo inka, el consumo de chicha y los festines desde una perspectiva de banquetes políticos". Boletín de Arqueología PUCP, 7: 355-363.

Domínguez Monedero, Adolfo

2002 "La moneda de los dioses: monedas y santuarios en Grecia". Actas del XIII Congreso Internacional de Numismática, Volumen I: 227-236. Ministerio de Cultura. Madrid.

Druc, Isabel

1998 "Producción y distribución de cerámica en Chavín de Huántar". En Burger, Richard: Excavaciones en Chavin de Huántar: 303-314. PUCP. Lima.
Earle, Timothy

1987 "Chiefdoms in archaeological and ethnohistorical perpectives". Annual Review of Anthropology, 16: 279-308.

Eliade, Mircea

1987 "Shamanism: an overview". En Encyclopedia of religion, Vol. 12: 8269-8273. MacMillan. New York.

Engels, Frederick

1976[1884] El origen de la familia, la propiedad privada y el estado. Roca. México D.F.

Espinoza, Waldemar (ed.)

1978 [1981] Los modos de producción en el Imperio de los Incas. Amaru. Lima.

Feathers, James, Jack Johnson y Silvia Rodriguez Kembel

2008 "Luminescence dating of monumental stone architecture at Chavín de Huántar, Perú". Journal of Archaeological Method and Theory, 15: 266-296.

Flannery, Kent

1972 "The cultural evolution of civilizations". Annual Review of Ecology and Systematics, 3: 339-426.

1998 "The ground plans of Archaic States". En Feinman, Gary y Joyce Marcus (eds): Archaic States: 15-57. School of American Research Press. Santa Fe.

Foucault, Michel

1976 Vigilar y castigar. Nacimiento de la prisión. Siglo XXI. Buenos Aires.

Fung, Rosa

1988 "The Late Preceramic and Initial Period". En Keatinge, Richard (ed.): An overview of peruvian prehistory: 67-98. Cambridge University Press. Cambridge.

2008[1999] "El proceso de neolitización en los Andes tropicales". En Arqueología y vida, 2: 75-136. Museo de Arqueología, Antropología e Historia. Universidad $\mathrm{Na}$ cional de Trujillo. Trujillo.

González, Andrea

2008 Las Representaciones figurativas como materialidad social y su aprehensión desde la arqueología: las cabezas clavas del sitio Chavín de Huántar, Perú. Estado de la cuestión e hipótesis. Trabajo de Investi- 
gación conducente al grado de Máster en Arqueología Prehistórica. Departamento de Prehistoria. Universidad Autónoma de Barcelona. Barcelona.

Haas, Jonathan

1982 The Evolution of Prehistoric State. Columbia University Press. New York.

Haas, Jonathan y Winifred Creamer

2006 "Crucible of andean civilization. The peruvian coast from 3000 to $1800 \mathrm{BC}$ ". Current Anthropology, 47(5): 745-756.

Ibarra, Bebel

2009 "Historia prehispánica de Huari: desde Chavín hasta los Inkas". En Ibarra, Bebel (ed.): Historia prehispánica de Huari. 3000 años de historia desde Chavín hasta los Inkas: 15-28. Instituto de Estudios Huarinos. Huari.

Inokuchi, Kinya

2008 "La arquitectura de Kunturwasi: secuencia constructiva y cronología de un centro ceremonial del periodo Formativo". Boletín de Arqueología PUCP, 12: 219. 247.

Insoll, Timothy

2004 Archaeology, ritual, religion. Routledge. Londres.

Isbell, William; Gordon McEwan (eds.)

1991 Huari administrative structure: prehistoric monumental architecture and state government. Dumbarton Oaks Research Library and Collection, Washington D.C.

1999 Mummies and mortuary monuments. A postprocessual prehistory of central andean social organization. University of Texas Press. Austin.

Jamieson, Ross

2005 "Colonialism, social archaeology and lo andino: historical archaeology in the Andes". World Archaeology, 37(3): 352 372.

Jennings, Justin; Brenda Bowser (eds.)

2008 Drink, power, and society in the Andes. University Press of Florida. Gainesville.

Johnson, Allen; Timothy Earle

2000 The evolution of human societies. Stanford University Press. Stanford.
Kauffmann, Federico

1963 La cultura Chavín. Compañía PeruanoSuiza. Lima.

1993 "Las ruinas de Chavín de Huántar. Una descripción somera”. Arqueológicas, 22: 15-36.

Kaulicke, Peter

2010 Las cronologías del Formativo. 50 años de investigaciones japonesas en perspectiva. PUCP. Lima.

Kaulicke, Peter; Tom Dillehay (eds.)

2005 "Encuentros: identidad, poder y manejo de espacios públicos". Boletín de Arqueología PUCP, 9.

Kaulicke, Peter; Lars Fehren-Schmitz; María KolpGodoy; Patricia Landa; Óscar Loyola; Martha Palma; Elsa Tomasto; Cindy Vergel; Burkhard Vogt

2009 "Implicancias de un área funeraria del periodo Formativo Tardío en el departamento de Ica". Boletín de Arqueología PUCP, 13: 289-322.

Kolata, Alan

1993 The Tiwanaku: portrait of an Andean civilization. Blackwell. Cambridge.

Kubler, George

1999 [1962] Arte y arquitectura en la América precolonial. Cátedra. Madrid.

Lane Fox, Robin

2007 El mundo clásico. La epopeya de Grecia y Roma. Crítica. Barcelona.

Lathrap, Donald

1982 "Complex iconographic features shared by Olmec and Chavin and some speculations on their possible significance". En Marcos, Jorge y Presley Norton (eds.): ler Simposio de Correlaciones Antropológicas AndinoMesoamericanas (Salinas, Ecuador, 25. 31 julio 1971): 18-26. ESPOL. Guayaquil.

Lull, Vicente

2007 Los objetos distinguidos. La arqueología como excusa. Bellaterra. Barcelona.

Lull, Vicente; Rafael Micó

2007 Arqueología del origen del estado. Las teorías. Bellaterra. Barcelona. 
Lumbreras, Luis G.

1970 Los templos de Chavín. Museo de Arqueología y Etnología de la Universidad Nacional Mayor de San Marcos. Editado por la Corporación Peruana del Santa. Lima.

1974 Los orígenes de las civilización en el Perú. Milla Batres. Lima.

1981 Arqueología de la América andina. Milla Batres. Lima.

2005[1989] "La aparición de las clases sociales, el estado y la Ciudad en los Andes Centrales". En Gonzales Carré, Enrique; Carlos Del Águila (eds.): Arqueología y Sociedad: 255-276. MNAAHP/INDEA/ IEP. Lima.

1993 Chavín de Huántar. Excavaciones en la galería de las Ofrendas. KAVA. Mainz am Rhein.

2005 [1995] "Acerca de la aparición del Estado". En Gonzales Carré, Enrique; Carlos Del Águila (eds.): Arqueología y Sociedad: 192-229. MNAAHP/INDEA/IEP. Lima.

2007 Chavin. Excavaciones arqueológicas. UAP. Lima.

Lumbreras, Luis. G; C. González; B. Lietaer

1976 Acerca de la función del sistema hidráulico de Chavín. Investigaciones de Campo, 2. Museo Nacional de Antropología y Arqueología. Lima.

Lumbreras, L. G.; R. Gebhard; W. Häusler; F. Kauffmann Doig; J. Riederer; G. Sieben; U. Wagner

2003 "Mössbauer study of ceramic finds from the galería de las Ofrendas, Chavín de Huántar". Hyperfine Interactions, 150: 51-72.

Llanos, Oscar

2010 "Cahuachi: residencia y paisaje sacralizado de un centro político Nazca". Revista Española de Antropología Americana, 40(1): 27-51.

Manzanilla, Linda

2001 "State formation in the new world". En Feinman, Gary y T. Douglas Price (eds.): Archaeology at the millennium. A sourcebook: 381-413. Springer. New York.

Makowski, Krzysztof

1997 "Dioses del templo de Chavín: reflexiones sobre la iconografía religiosa". En
Varón, Rafael; Javier Flores (eds.): Arqueología, antropología e historia en los Andes. Homenaje a María Rostworowski: 501-525. IEP/BCRP. Lima.

2008a "Andean urbanism". En Silverman, Helaine y William H. Isbell (eds.): Handbook of South American Archaeology: 633-657. Springer, New York.

2008b "iReyes o curacas? las particularidades del ejercicio del poder en los Andes prehispánicos". En Makowski, Krzysztof (ed.): Señores de los reinos de la luna: 1-9. Banco de Crédito del Perú. Lima.

Marcus, Joyce; Gary Feinman

1998 "Introducción". En Feinman, Gary; Joyce Marcus (eds.): Archaic States: 3-13. School of American Research Press. Santa Fe.

Masato, Sakai; Juan José Martínez

2008 "Excavaciones en el templete de Limoncarro, valle bajo de Jequetepeque". Boletín de Arqueología PUCP, 12: 171-201.

Mauss, Marcel

1971[1924] "Ensayo sobre los dones. Razón y forma del cambio en las sociedades primitivas". En Sociología y Antropología: 153-263. Tecnos. Madrid.

Mesía, Christian

2007 Intrasite spatial organization at Chavin de Huantar during the Andean Formative: three dDimensional modeling, stratigraphy and ceramics. Tesis doctoral. Departamento de Ciencias Antropológicas. Universidad de Stanford. Palo Alto.

Milla Villena, Carlos

2008 Génesis de la cultura Andina. Amaru Wayra. Lima.

Millaire, Jean-François

2009 "Gallinazo and the tradición norcosteña”. En Millaire, Jean-François; Magali Morlion (eds.): Gallinazo. An early cultural tradition on the peruvian north coast: 1-16. Cotsen Institute of Archaeology Press. Los Angeles.

2010a "Primary state formation in the Virú valley, North coast of Peru. Proceedings of National Academy of Sciences, 107 (14): 6186-6191. 
2010b "Moche political expansionism as viewed from Virú. Recent achaeological work in the close periphery of a hegemonic CityState System". En Quilter, Jeffrey; Luis Jaime Castillo (eds.): New perspectives on Moche political organization: 223-251. Dumbarton Oaks. Washington D.C.

Moore, Jerry

1996 Architecture and Power in the Ancient Andes. The Archaeology of Public Buildings. Cambridge University Press. New York.

2005 Cultural Landscapes in the Ancient Andes. Archaeologies of Place. University Press of Florida. Gainesville.

Morales, Daniel

2008 "The importance of Pacopampa: architecture and iconography in the Central Andean Formative". En Conklin, William y Jeffrey Quilter (eds.): Chavin: Art, Architecture, and Culture: 143-162. Cotsen Institute of Archaeology, UCLA. Los Angeles.

Morris, Brian

2006 Religion and anthropology. A critical introduction. Cambridge University Press. New York.

Nesbitt, Jason; Belkys Gutiérrez; Segundo Vásquez 2008 "Excavaciones en Huaca Cortada, complejo Caballo Muerto, valle de Moche: un informe preliminar". Boletín de Arqueología PUCP, 12: 261-286

Patterson, Thomas

1991 The Inca Empire. The formation and disintegration of a pre-capitalist state. Berg. Oxford.

Pozorski, Shelia

1987 "Theocracy vs. militarism: the significance of the Casma valley in understanding Early State formation”. En Haas, Jonathan; Shelia Pozorski y Thomas Pozorski (eds.): The origins and development of the Andean State: 15-30. Cambridge University Press. Cambridge.

Pozorski, Thomas

1983 "The Caballo Muerto complex and its place in the Andean chronological sequence". Annals of Carnegie Museum, 52: $1-40$.
Pozorski, Shelia; Thomas Pozorski

1992 "Early civilization in the Casma valley, Peru". Antiquity, 66: 845-870.

1994 "Early andean cities". Scientific American, 270(6): 66-72.

2008 "Early cultural complexity on the Coast of Peru". En Silverman, Helaine; William Isbell (eds.): Handbook of south american archaeology: 607-631. Springer. New York.

Price, Neil

2001 The archaeology of shamanism. Routledge. Londres.

Ravines, Rogger

1984 "Sobre la formación de Chavín: imágenes y símbolos". Boletín de Lima, 35:27-45

Renfrew, Colin; Paul Bahn

1998 Arqueología. Teorías, métodos y práctica. Akal. Madrid.

Reinhard, Johan

1985 "Chavín and Tiahuanaco: a new look at two Andean ceremonial centers". National Geographic Research, 1(3): 395-422.

Rick, John

2005 "The evolution of authority and power at Chavín de Huántar, Peru". En Vaughn, Kevin; Dennis Ogburn; Christina Conlee (eds.): Foundations of power in the prehispanic Andes. Archaeological papers of the American Anthropological Association, 14: 71-89. Arlington.

2006 "Un análisis de los centros ceremoniales del periodo Formativo a partir de los estudios en Chavín de Huántar". Boletín de Arqueología PUCP, 10: 201-214.

2008 Context, construction, and ritual in the development of authority at Chavin de Huántar”. En Conklin, William; Jeffrey Quilter (eds.): Chavin: art, architecture, and culture: 3-34. Cotsen Institute of Archaeology, UCLA. Los Angeles.

Rick, John; Rosa Mendoza

2003 "Marino Gonzales: 1916-2001. El hombre de Chavín y su mundo". Arqueológicas, 26: 17-26.

Rick, John; Christian Mesía; Daniel Contreras; Silvia Kembel; Rosa Rick; Matthew Sayre; John Wolf

2009 "La cronología de Chavín de Huántar y sus implicancias para el periodo Forma- 
tivo". Boletín de Arqueología PUCP, 13: 87-132.

Rodríguez Kembel, Silvia

2008 "The architecture at the monumental center of Chavín de Huántar: sequence, transformations, and chronology". En Conklin, William y Jeffrey Quilter (eds.): Chavin: art, architecture, and culture: 35 81. Cotsen Institute of Archaeology, UCLA. Los Angeles.

Roe, Peter

1974 "A further exploration of the Rowe Chavín seriation and its implications for North Central coast chronology". Studies in Pre-Columbian art and archaeology, 13. Dumbarton Oaks, Washington D.C.

Rowe, John

1963 "Urban settlements in ancient Peru". Nawpa Pacha, 1: 1-27.

1967 "Form and meaning in Chavin art". En Rowe, John; Dorothy Menzel (eds.): Peruvian Archaeology. Selected Readings: 72 103. Peek publication. Palo Alto.

Sanoja, Mario

1982 "Modos de producción precapitalistas en Venezuela". En Teorías, métodos y técnicas en Arqueología: 219-230. Reimpresiones del Boletín de Antropología Americana. México D.F.

Schreiber, Katherine

1992 Wari imperialism in middle Horizon Peru. Museum of Anthropology, University of Michigan. Ann Arbor.

2001 "The Wari Empire of Middle Horizon Peru: the epistemological challenge of documenting an empire without documentary evidence". En Alcock, Susan; Terence D'Altroy; Kathleen Morrison; Carla Sinopoli (eds.): Empires. Perspectives from Archaeology and History: 70 . 92. Cambridge University Press. Cambridge.

Seki, Yuji; Juan Pablo Villanueva; Masato Sakai; Diana Alemán; Mauro Ordoñez; Walter Tosso; Araceli Espinoza; Kinya Inokuchi; Daniel Morales

2008 "Nuevas evidencias del sitio arqueológico de Pacopampa, en la sierra norte del Perú". Boletín de Arqueología PUCP, 12: 69-95.
Sendón, Pablo

2006 "Ecología, ritual y parentesco en los Andes: notas a un debate no perimido". Debate Agrario, 40-41: 273-297.

Service, Elman

1984[1975] Los orígenes del estado y la civilización. El proceso de evolución cultural. Alianza. Madrid.

Shady, Ruth

2009 "Caral-Supe y su entorno natural y social en los orígenes de la civilización". En Marcus, Joyce; Patrick Ryan Williams (eds.): Andean civilization. A tribute to Michael Moseley: 99-120. Cotsen Institute of Archaeology. Los Angeles.

Shibata, Koichiro

2008 "El sitio de Cerro Blanco de Nepeña dentro de la dinámica interactiva del periodo Formativo". Boletín de Arqueología PUCP, 12: 287-315.

Silverman, Helaine

1995 "Recent archaeological investigations on the South Coast of Peru: critique and prospects". Journal of Steward Anthropological Society, 23(1, 2):13-41.

Smith, Michael; Katharina Schreiber

2005 "New world states and empires: economic and social organization". Journal of Archaeological Research, 13(3): 189. 229.

2006 "New world states and empires: politics, religion, and urbanism". Journal of Archaeological Research, 14(1): 1-52.

Spencer, Charles

2010 "Territorial expansion and primary state formation". Proceedings of National Academy of Sciences, 107(16): 7119-7126.

Spencer, Charles; Elsa Redmond

2004 "PrimarystateformationinMesoamerica". Annual Review of Anthropology, 33:173199.

Stanish, Charles

2001 "The origin of states societies in South America". Annual Review of Anthropology, 30: 41-64.

2003 Ancient Titicaca. The evolution of social power in the Titicaca aasin of Peru and 
Bolivia. University of California Press. Berkeley y Los Angeles.

Stone, Rebecca

1983 "Possible uses, roles, and meanings of Chavin-Style painted textiles of South Coast Peru". En Sandweiss, Daniel (ed.): Investigations of the Andean Past. Papers from the First Annual Northeast Conference on Andean Archaeology and Ethnohistory: 51-74. Cornell Latin American Studies Program. Cornell.

Tantaleán, Henry

2008 "Las miradas andinas. Arqueologías y nacionalismos en el Perú del Siglo XX". Revista de Arqueología Suramericana, 4(1): 34-52.

2010 "El pasado tras del espejo: arqueología y nacionalismo en el Perú". En Nastri, Javier; Lucio Meneses (eds.): Historias de la arqueología sudamericana: 137-162. Fundación de Historia Natural/Universidad Maimónides. Buenos Aires.

Tello, Julio

1923 Wiracocha. Reimpreso de la Revista Inca. Universidad Nacional Mayor de San Marcos. Lima.

1943 "Discovery of the Chavín culture in Peru". American Antiquity, 9(1): 135-160.

1960 Chavín. Cultura matriz de la civilización andina. UNMSM. Lima.

Topic, John

2003 "From stewards to bureaucrats: architecture and information flow at Chan Chan, Peru". Latin American Antiquity, 14(3): 243-274.

Vargas, Pedro

2005 Análisis de los signos gráficos del Obelisco Tello de Chavín de Huántar. Una propuesta estructural y lingüística. Tesis de Licen- ciatura. Escuela Académico Profesional de Arqueología. Universidad Nacional Mayor de San Marcos. Lima

Verano, John

2001 "The physical evidence of human sacrifice in ancient Peru". En Benson, Elizabeth; Anita Cook (eds.): Ritual sacrifice in ancient Peru: 165-184. University of Texas Press. Austin.

Victorio, Patricia

2010 "Reflexiones en torno al estudio del arte del Perú Antiguo". Revista del Museo Nacional, L: 47-64.

Wagner, U.; F. E. Wagner; A. Stockklauser; R. Salazar; J. Riederer; F. Kauffmann Doig

1986 "Mössbauer analysis Of recent ceramic finds from Chavin". Hyperfine Interactions, 29: 1113-1116.

Watanabe, Shinya

2008 "Dos monolitos del sitio de Congona, Sierra Norte del Perú". Boletín de Arqueología PUCP, 12: 53-67.

Weber, Max

1977[1922] ¿Qué es la burocracia?. La Pléyade. Buenos Aires.

Winkelman, Michael

2010 Shamanism. A biopsychosocial paradigm of consciousness and healing. Praeger. Santa Barbara.

Wright, Henry

1977 "Recent research on the origin of the state". Annual Review of Anthropology, 6: 379-397.

Yoffee, Norman

2005 Myths of Archaic State. Evolution of the earliest cities, states, and civilizations. Cambridge University Press. Cambridge. 